4 norden 



\section{Protozoan Parasites in Sewage Sludge}




\section{Protozoan Parasites in Sewage Sludge}

TemaNord 2006:596

(C) Nordic Council of Ministers, Copenhagen 2006

ISBN 978-92-893-1447-3

Copies: Print-on-Demand

This publication can be ordered on www.norden.org/order. Other Nordic publications are available at www.norden.org/publications

Nordic Council of Ministers

Store Strandstræde 18

DK-1255 Copenhagen K

Phone (+45) 33960200

Fax (+45) 33960202
Nordic Council

Store Strandstræde 18

DK-1255 Copenhagen K

Phone (+45) 33960400

Fax (+45) 33111870

www.norden.org

\section{Nordic cooperation}

Nordic cooperation is one of the world's most extensive forms of regional collaboration, involving Denmark, Finland, Iceland, Norway, Sweden, and three autonomous areas: the Faroe Islands, Greenland, and Åland.

Nordic cooperation has firm traditions in politics, the economy, and culture. It plays an important rol in European and international collaboration, and aims at creating a strong Nordic community in a strong Europe.

Nordic cooperation seeks to safeguard Nordic and regional interests and principles in the global community. Common Nordic values help the region solidify its position as one of the world's most innovative and competitive. 


\section{Content}

Preface

Summary

Sammanfattning

Objectives

1. Giardia and Cryptosporidium in the society......

1.1 Giardiasis and cryptosporidiosis - host specificity and epidemiology ................ 15

1.2 Giardia and Cryptosporidium and possible zoonotic transmission ...................... 18

2. Giardia and Cryptosporidium in Wastewater and Sewage Sludge ............................. 21

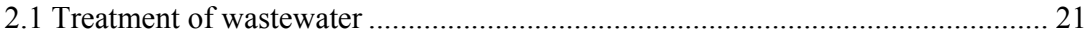

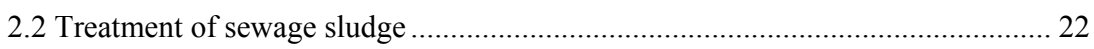

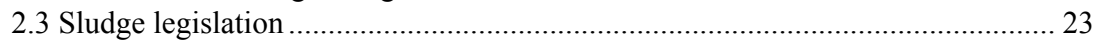

2.4 Occurrence and removal of protozoan parasites in sewage treatment systems..... 25

2.5 Risks connected with protozoan parasites in wastewater and sludge ................... 28

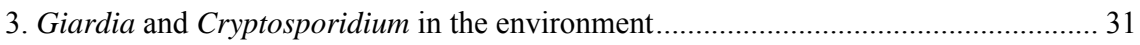

3.1 Occurrence, survival and transmission ............................................................. 31

3.2 Giardia and Cryptosporidium in surface water used for drinking water production and pathways of (oo)cysts into the environment.......................... 32

3.3 The occurrence of (oo)cysts in treated sewage water ......................................... 34

3.4 Environmental factors for survival of (oo)cysts ................................................. 34

4. Drinking water treatment, outbreaks and methods of detection and viability ................ 37

4.1 Drinking water treatment................................................................................. 37

4.2 Waterborne and food associated outbreaks of Giardia och Cryptospordium ........ 39

4.3 Detection methods, viability and Infectivity assays ............................................ 41

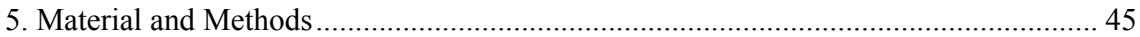

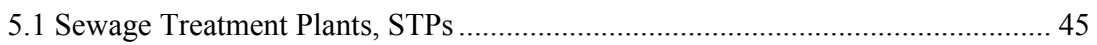

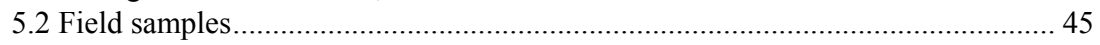

5.3 Laboratory study/Microbiological analyses....................................................... 45

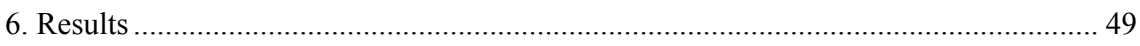

6.1 Giardia and Cryptosporidium in sewage and sludge........................................ 49

6.2 Cryptosporidium parvum survivability in sludge at different temperatures ......... 52

6.3 Indicator organisms in the untreated and treated sludge ..................................... 53

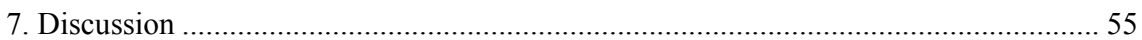

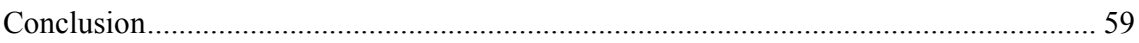

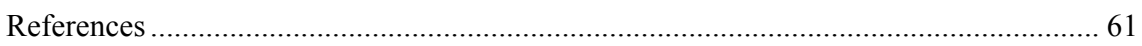





\section{Preface}

This project was initiated as part of an evaluation of sludge treatment processes based on the suggested new EU legislation (EC 2000REF). This report covers the different parts of the project:

1. A literature review of Giardia and Cryptosporidium in the society and the environment.

2. A field study of occurrence and removal of the protozoa during wastewater and sludge treatment and;

3. A laboratory study to further evaluate the efficiency of sludge treatment at various temperatures.

The detailed objectives are included below

The literature study follows a theoretical chain of events that has implications on the risk for exposure, with the subsequent possibility of becoming infected by the protozoa.

The focus is on the Nordic countries, supported by reviewed international literature where relevant studies regarding certain aspects are limited or lacking from the region. The prevailing international literature on Giardia and Cryptosporidium is immense due to intense research during the last two decades, and it has not been possible to include all relevant publications.

In Chapter 1 the occurrence of Giardia and Cryptosporidium in the society are presented as well as their relationship to both animals and humans. The shedded cysts and oocysts will reach sewage treatment plants and be present both in treated wastewater and sewage sludge. This is further dealt with in Chapter 2. Studies of reduction effiency in different treatment processes are reported, where a limitation is the biased information related to occurrence versus viability. The risks related to human exposure due to the use of wastewater and sludge has been evaluated in a few quantitative risk assessment investigations and relevant results are reported. The treated wastewater will end up in a surface water recipient with possible additional inputs through run-off from agricultural land (that e.g. have been subjected to sludge application or grazing animals). Subsequently ground- and surface waters used for drinking water production, irrigation or for recreational activities can become contaminated by Giardia and Cryptosporidium (dealt with in Chapter 3). The occurrence in raw water and the survival of cysts and oocysts in this environment is crucial for the further risk characterization. The survival in soil and on crops will further be decisive for exposure and risk for disease and sec- 
ondary spread in the environment. The chapters 2 and 3 dealing with presence and survival in various environments, including wastewater and sludge, continuously refers to analytical methods used for determining the viability of cysts and oocysts. Since this is crucial for the risk assessments different viability methods, including the one used in the present study, are specifically dealt with in Chapter 4 also including a brief background for concentrating and detecting methods of protozoa in water and environmental samples.

Outbreaks of Giardia and Cryptosporidium have been reviewed and exemplified in relation to various routes of transmission in Chapter 4. The further reduction of (oo)cysts in drinking water treatment are of special concern (see Chapter 4) since drinking water outbreaks has resulted in a large number of Giardia and Cryptosporidium infections, and due to the high resistance of cysts and oocysts against chlorine disinfections.

The further investigations of the occurrence and viability of Giardia and Cryptosporidium in wastewater and sludge are reported in Material and Methods (Chapter 5) and Results (Chapter 6). Results from these field investigations are followed by the results from the laboratory study (Chapter 6).

In the Discussion (Chapter 7) both the obtained results and conclusions from the literature review are summarized. The different aspects in a risk management approach that impact on risks for Giardia and Cryptosporidium in relation to sludge handling and use are accounted for. Suggestions for further applied research are also included.

This report is targeted towards investigators as well as decision makers, who need a background summary or support for decisions. In the different sections, we have further wanted to highlight areas where knowledge is limited in spite of the vast international investigations performed, and the focus on occurrence versus viability in the assessments of risk. 


\section{Summary}

The project has focused on sewage and sludge treatment within a broader frame of background information regarding Giardia and Cryptosporidium. The target area is the Nordic countries and relationship between the risk of transmission and the risk of aquiring infections from the environment. The objectives were further to exemplify the occurrence and viability of Giardia and Cryptosporidium through investigations in raw sewage and untreated or treated sludge from two sewage treatment plants. Viability of Giardia and Cryptosporidium (oo)cysts was assesed by a fluorescent in situ hybridization method (FISH) as the primary alternative for sludge samples and laboratory evaluations. This methodology was to some extent useful as an indicator of viability for the field samples but was more valuable in thelaboratory experiments. The comparative reduction efficiency between thermophilic and mesophilic sludge treatments were selected for further asessed. The treatment plants selected as representative of the treatments were Henriksdal in Stockholm utilising mesophilic digestion and Tegeludden in Kalmar utilising thermophilic digestion. In addition to sludge treatment the occurrence of Giardia and Cryptosporidium in wastewater was included. For comparisons the following additional indicator organisms were included in the field study; E.coli and intestinal enterococci for bacteria and coliphages as an indicator for viruses. The occurrence and survivability of protozoan parasites in sludge are seen as the most important objective for this work in order to serve as a basis for the European regulation and for an assessment of the risk with treatment of sewage sludge.

This study shows that Giardia cysts occur in higher concentrations (mean conc.160-800 cysts/L) than Cryptosporidium oocysts (mean conc. 3-4 oocysts/L) in influent sewage from two investigated sewage treatment plants. Large variation in concentration of cysts was observed (281370 Giardia cysts/L) as proportion of viable cysts (16-46\%). Giardia cysts were also detected in higher concentration than Cryptosporidium oocysts (only detected at two occasions) in the sludge. Giardia cyst concentration in the treated sludge was reduced in the mesophilic treatment but not in the thermophilic. This may be due to large variations in (oo) cysts concentration and difficulties to match samples. A few Giardia cysts were still viable after both thermophilic and mesophilic treatment. It is possible that fractions of the sludge are exposed to shorter exposure time than the mean retention time.

Laboratory scale experiments with heat treatment; $50^{\circ} \mathrm{C}$ (thermophilic digestion), $35^{\circ} \mathrm{C}$ (mesophilic digestion) and $10^{\circ} \mathrm{C}$ showed a rapid decline in viability of Cryptosporidium oocysts seeded in sludge. Full inactiva- 
tion was reached whitin two days incubation at $50^{\circ} \mathrm{C}$ and after 8 days in $35^{\circ} \mathrm{C}$. All oocysts were inactivated after 22 days in $10^{\circ} \mathrm{C}$. Other factors than temperature seems to influence the inactivation. An initial die-off effect was observed in the sludge samples but not in oocysts seeded into water. Future studies may give informtion of other factors influencing the reduction of viability in sludge.

The occurrence of viable Giardia cysts in high concentrations in the sludge may be a risk if the sludge is not treated enough. This study shows that full inactivation is achived whithin a few days at ambient temeratures. A few viable cysts detected in treated sludge may be due to methodological limitations or possible shorter exposure than mean retention time. For future studies a detailed approach regarding retention time and possible matched samples.

The project has not included a differentiation of Cryptosporidium and Giardia-species or bio/genotypes. The presence of human-specific Cryptosporidium or Giardia are of interest for risk assessments of sewage and sludge handling, but are not of specific concern related to suitable sludge treatment processes. The speciation and sub-speciation should be considered in future work.

According to the NRC (2002) a number of epidemiological studies and risk assessments are needed in order to get more clarity in how high the risks associated with sludge are and how these should be handled. The results obtained in this study could be used as valuable background material in such studies. 


\section{Sammanfattning}

Projektet har fokuserat på avlopp- och slambehandling med bakgrund av en bredare bas av information gällande de parasitära protozoerna Giardia och Cryptosporidium. Målområdet är de Nordiska länderna och relationen mellan risken för spriding av dessa protozoer till miljön och den risk som kan föreligga för att infekteras från miljön.

Ett ytterligare mål var också att exemplifiera förekomsten och viabiliteten av Giardia och Cryptosporidium genom undersökningar i obehandlat avloppsvatten, obehandlat och behandlat slam från två utvalda avloppsreningsverk. För information om viabilitet av Giardia och Cryptosporidium användes en "Fluorescent in situ hybridization" metod (FISH) som förstahandsval för direktmätning av slamprover och till den laborativa delen av studien. FISH-metoden var till viss del användbar som indikator för viabilitet för proverna från avloppsreningsverket men visade sig vara mer användbar för de laborativa överlevnadsförsöken. Henriksdals avloppsreningsverk i Stockholm med mesofil rötning och Tegeludden avloppsreningsverk i Kalmar med termofil rötning valdes för fältundersökningar En jämförelse mellan reduktionen av protozoernas överlevnad efter den termofila och den mesofila behandlingen valdes för fortsatta undersökningar. Förutom slambehandling inkluderades förekomsten av Giardia och Cryptosporidium i avloppsvattnet. För jämförelse inkluderades följande indikatororganismer i fältstudien; E.coli och intestinala enterococcer för bakterier och colifager som indikatorer för virus.

Förekomsten och överlevnaden av parasitära protozoer i slam ses som det viktigaste målet inom detta arbete för att användas som en bas för Europeiska föreskrifter och för en riskvärdering för slambehandling.

I denna studie visas att förekomsten av Giardia cystor är betydligt högre än Cryptosporidium oocystor (medel 160/800 cystor och 3/4 oocystor/L) i de inkommande avloppsvattnen från de två undersökta avloppsreningsverken. Koncentrationen av cystor i det inkommande avloppsvattnet varierade mycket mellan provtillfällena (28-1370 Giardia cystor/L) liksom andelen viabla cystor (16-46\%). Även i slammet, det obehandlade och behandlade återfanns Giardia cystor i högre halter än Cryptosporidium oocystor som bara detekterades vid två tillfällen. I Henriksdals avloppsreningsverk reducerades antalet Giardia cystor men inte vid Tegeluddens avloppsreningsverk. Detta kan bero på svårigheten att ta prover som matchar varandra, variationerna kan vara stora. Endast ett fåtal Giardia cystor var fortvarande viabla efter termofil och mesofil rötning. Det är möjligt att delfraktioner av slammet utsätts för en kortare uppehållstid vid kontinuerlig drift. 
Studier i laborativ miljö med temperaturer på $50^{\circ} \mathrm{C}$ (termofil rötning) och $35^{\circ} \mathrm{C}$ (mesofil rötning), och $10^{\circ} \mathrm{C}$ visade på en snabb initial reduktion av viabiliteten hos Cryptosporidium oocystor i slam. Full inaktivering uppnåddes efter två dagars inkubation i $50^{\circ} \mathrm{C}$ och efter 8 dagar i $35^{\circ} \mathrm{C}$. Alla oocystor inaktiverade efter 22 dagar i $10^{\circ} \mathrm{C}$. En initial avdödning skedde i slamprover men inte i vatten. Andra faktorer än temperatur kan påverka avdödningen. Fortsatta studier kan ge ytterligare information om andra faktorer som kan påverka avdödning. Förekomsten av viabla Giardia cystor i höga koncentrationer i inkommande avloppsvatten, sedimenterat till slam kan innebära risker om slammet inte behandlas tillräckligt. Denna studie visar att full inaktivering sker inom några få dygn vid de temperaturer som används vid rötning. Ett fåtal viabla cystor detekterades efter både termofil och mesofil slambehandling. Detta kan bero på metodologiska faktorer men även möjligheten att delfraktioner av slammet haft en kortare uppehållstid än medeluppehållstiden. För fortsatta studier rekommenderas en mer detaljerad studie gällande uppehållstider och att försöka matcha prover före och efter behandling.

Detta projekt har inte inkluderat skillnaden mellan olika genotyper av Giardia och Cryptosporidium. Förekomsten av human-specifika genotyper av Cryptosporidium är av intresse för risk analyser av avlopps och slamhantering men är inte direkt relaterade till specifika slambehandlingsprocesser. Differentiering av olika arter och subarter bör inkluderas i framtida arbeten.

I enlighet med NRC (2002) behövs ett antal epidemiologiska studier och risk bedömningar för att få en klarare bild av risker associerade med slam och hur det ska bli behandlat. Resultaten från denna studie kan vara användbara som bakgrundsmaterial till sådana studier. 


\section{Objectives}

Giardia and Cryptosporidium are two intestinal protozoan parasites that can cause diarrhoea in both humans and animals. Large amounts of infective (oo)cysts, the robust and viable stage of Cryptosporidium and Giardia are excreted from infected hosts. Transmission of Cryptosporodium and Giardia may occur direct from person to person, animal to person or indirectly via contaminated water or food. Sludge from sewage treatment plants may be spread to agricultural and recreational fields as a fertilizer/soil improver and may contain (oo)cysts able to infect humans or animals or contaminate water used for drinking water production. Knowledge about the occurrence, reduction and survival of protozoa in sludge after different treatments methods is deficient. Investigations in the Nordic countries have shown that Giardia and Cryptosporidium frequently occur in surface water (Parasites in Water Tema Nord report 2003:552). Knowledge about their occurrence in sewage sludge is however largely lacking. In a forthcoming EU-directive, a proposal of different treatment methods for sludge is expected. Changes in sludge management are also occurring within the Nordic countries and evaluations of efficiency of treatment methods and risks associated with sludge use have been anticipated.

The first objective of the present study was therefore to conduct a literature study regarding the following issues:

- Presence of Cryptosporidium and Giardia in the society

- Occurrence of the protozoan parasites in wastewater and sludge

- Reduction during wastewater treatment

- Survival/inactivation in materials that can give information regarding survival in wastewater, sludge and soil.

- The occurrence of protozoan parasites in surface and groundwater. Drinking water treatment.

- Methods to measure viability.

With this background the project aimed to investigate the occurrence and reduction of the protozoan pathogens Giardia and Cryptosporidium in sewage sludge and wastewater in selected sewage treatment plants with different treatment methods. Complementary methods for measuring viability were to be evaluated in laboratory scale and applied directly to sludge and sewage samples. 
The specific aims can be summarised as follows:

- Planning of survival studies with specific focus on testing viability methods on sludge samples and choosing treatment methods to be evaluated in laboratory and field studies

- Assessing the occurrence of Cryptosporidium and Giardia in wastewater and sewage sludge by sampling wastewater and sludge during different stages of treatment at selected treatment plants

- Assessing the survival of Cryptosporidium and Giardia in laboratory studies relating the parameters to specific treatments of sludge

- Studying the inactivation of Cryptosporidium and Giardia in the field by sampling sludge before and after treatment

- Analysing the reduction of indicator bacteria and coliphages during sludge treatment

Giardia and Cryptosporidium occur in different species of animals and humans and with molecular techniques it is possible to distinguish between non-pathogenic and pathogenic species to humans. Samples from this project will be saved for subsequent analysis that may supply valuable information about the different genotypes of (oo)cysts occurring in wastewater. These results can in combination with the results from the present study be utilised in further risk assessments and epidemiological investigations and research. 


\section{Giardia and Cryptosporidium in the society}

Giardia and Cryptosporidium are protozoan parasites causing diarrhoeal disease in humans, livestock and other animals throughout the world. They are more frequently occurring in countries with low sanitary standards where the load of parasites is higher both in the population and in the environment, than in industrialized countries. Especially children have a higher risk of getting infected. Even though the burden of disease from these parasites is higher in developing countries, Giardia and Cryptosporidium are important causes of disease in the industrial world, like in the Nordic countries.

Several factors contribute to the importance of these organisms in the society and in the environment.

- The transmission routes are faecal-oral.

- Certain species and genotypes are zoonotic.

- Large amounts of Giardia cysts and Cryptosporidium oocysts are excreted from infected humans and animals.

- The (oo)cysts are robust and can stay viable for a long time in the environment.

- The infectious dose is low; just a few (oo)cysts can cause disease.

- Conventional treatment methods in drinking water production, such as chlorination, do not inactivate the (oo)cysts considerably.

These factors have contributed to Giardia and Cryptosporidium as the causative agents in several waterborne outbreaks. In addition, incompletely treated sewage and sludge may also contribute to the burden of (oo)cysts in the environment and the possible transmission of disease.

\subsection{Giardiasis and cryptosporidiosis - host specificity and epidemiology}

Giardia: Different species of Giardia and Cryptosporidium are hostspecific, but some are able to infect a wide range of animals. Molecular methods have shown the occurrence of at least 6 different species of Giardia. Molecular subgenotyping has increased the understanding of how these parasites are transmitted and their relative relevance. Of the Giardia species only G. intestinalis (same as. G. lamblia or G. duode- 
nalis), type A and B infects humans. The other species have the following known hosts; G. agilis (amphibians), G. muris (rodents), G. psittaci (birds), G. ardea (birds) and G. simondi (rats). The subtypes of Giardia intestinalis are named assembles. Assembles A and B are associated with humans, primates and dogs, C and D with dogs, E with cattle and hoofed livestock, whereas $\mathrm{F}$ associated with cats has been proposed to be a separate specie (Thompson and Monis 2004) and G with rats. The transmission of Giardia cysts will be further discussed in the following chapter.

Cryptosporidium: Up to now 14 species of Cryptosporidium have been identified in a wide range of animals (Hunter and Thompson 2005). Some Cryptosporidium species are host specific and have been identified in wild and domestic animals, pets, reptiles and in fish. C. parvum and $C$. hominis are the species most commonly identified in humans, although other species like C. melegridis, C. felis, C. canis and C. muris also have been associated with rare human cases mainly in immunocompromised patients but also in some immunocompetent patients (Pedraza-Dias et al. 2000). C. parvum is a zoonotic agent and common in cattle and other livestock. Direct contact with infected cattle is a risk factor for aquiring cryptosporidiosis.

Antibiotics to treat giardiasis are available but efficient treatments against human cryptosporidiosis are still lacking. Cryptosporidiosis is normally self-limiting in healthy individuals but can cause chronic diarrhoea in immunocompromised individuals such as AIDS-patients.

The molecular identification of different types and subtypes of Cryptosporidium (as well as for Giardia) might be a useful tool for epidemiological source tracking in outbreak situations. A selected gene is amplified with PCR (polymerase chain reaction) and the amplified product is then further analysed with RFLP (Restriction Fragment Length Polymorfism) or other subgenoyping methods as sequensing. For Cryptosporidium the following genes have been studied: HSP (Heat shock protein) 70 (Rochelle et al. 1997), COWP (Cryptosporidium Oocyst Wall Protein) (Spano et al.1997), ssrRNA (Xiao et al. 2001). Multilocus genotyping at microsatellite markers (Caccio et al. 2000) and single strand conformation polymorphism (SSCP) (Gasser et al. 2003) are tools specific for C. parvum and C. hominis and do not identify DNA from most Cryptosporidium species and genotypes. Examples of genes studied in the Giardia genome are the gene coding for B-giardin production (Caccio et al. 2002), the glutamate dehydrogenase locus (Read et al. 2004) and the 16S-rRNA locus (Appelbee et al. 2003).

In Great Britain with a history of regular laboratory identification of Cryptosporidium, molecular methods have successfully been used in epidemiological investigations. Seasonal duality in human cases of cryptosporidiosis have been recognised in the country, with one peak in spring and another in summer/early autumn. During the spring C. parvum 
type B (C. parvum) is predominant and the other peak during summer $C$. parvum type A (C. hominis). Mc Laughlin et al. (2000) hypothesise that the spring peak origin from livestock and the peak after the summer holiday's origin from travellers from abroad and/or through sewage contaminated water.

Enemark et al. (2002) investigated 271 isolates of human and animal origin in Denmark. Of the isolates of human origin $40.9 \%$ were of the zoonotical genotype and $56.8 \%$ anthroponotic.

In Sweden and Norway giardiasis is a reportable disease. About 1500 Swedish cases per year are reported to SMI (The Swedish Institute for Infectious Disease Control). Of this $2 / 3$ are infected abroad. In Norway 300-400 cases of giardiasis are reported yearly to the National Institute of Public Health. Cryptosporidiosis became reportable in Sweden 2004. Before that the surveillance system was built on voluntary laboratory reporting. About 100 cases of cryptosporidiosis are reported in Sweden per year. In Norway new cases of cryptosporidiosis in AIDS-patient have to be reported to Meldingssystem för smittsomme sykdommer-MSIS at Folkhelseinstitutet (National Institute of Public Health). Between 19832000 nine cases of cryptosporidiosis were reported to MSIS. Cryptosporidiosis is not a reportable disease in Denmark and fewer than 100 cases are registered yearly to Statens Seruminstitut. In Finland the information about cryptosporidiosis are built on voluntary laboratory reporting with few cases per year; 7-18 cases/year was during 2001-2005 registred to the National Public Health Institute (KTL). The cases of giardiasis are about 200-300 per year for the years 2001-2005.

The reported cases of giardiasis and cryptosporidiosis in the Nordic countries are probably underestimated. Hörman et al. (2004) have in a meta-analyse investigated published literature with prevalence data from the Nordic countries and compared this with the actual reported numbers. They found that 1 reported case corresponded to 867 cases of Giardia infection in Finland, 1:254 in Sweden and 1:634 in Norway. The corresponding numbers for cryptosporidiosis were 1:15,181 in Finland and 1:4,072 in Sweden. According to other international studies the underreporting is less, estimated to $10-45$ times, resulting in incidences of $0.054 \%$ for Giardia and $0.081 \%$ for Cryptosporidium in England (Wheeler et al. 1999) and $0.7 \%$ for Giardia and $0.11 \%$ for Cryptosporidium in The US (Mead et al. 1999). Nygård et al. (2003) point out that mainly patients that have been abroad are examined; persons infected in their home country are seldom recognised, leading to a higher underreporting for country-specific cases. The fact that both Cryptosporidium and Giardia have been detected in water used for drinking water production in Finland (Hanninen 2004), in Sweden (Hansen and Stenström 1998) as well as in Norway (Robertson 2001) highlight the risk of being infected within the Nordic countries via contaminated drinking water or 
other environmental sources and that the risk scenarios are not sufficiently evaluated.

Several factors thus contribute to the probability of underreporting:

- Patients may not visit the doctor.

- Giardia samples are more often taken after visits abroad.

- The knowledge between individual medical doctors varies.

- Few faecal samples are sent to the laboratories. At the laboratory the samples have to be specially treated to detect Cryptosporidium, which is not a routine in most parasitology laboratories.

An indirect way of assessing the load of parasites within the society is to measure the levels of pathogens in the raw sewage. The load of Giardia cysts entering sewage treatment plants is high in Sweden, approximately 4,000 cysts/L (Ottoson et al. 2006). The author suggests a daily infection incidence of $1.95 \%$ compared to the reported cases in Sweden based on the level of Giardia cysts (2004; 1,360 cases) and a daily incidence of $0.16 \%$. Cryptosporidium oocysts have been detected in lower concentrations in the same study, indicating that cryptosporidiosis may be less prevalent than giardiasis (symptomatic or asymptomatic) whithin the society. Higher densities of Giardia than Cryptosporidium in the raw sewage water have also been detected in other investigations $i$ e in Italy (Caccio et al. 2002).

\subsection{Giardia and Cryptosporidium and possible zoonotic transmission}

A high prevalence of Giardia and Cryptosporidium in livestock or wild animals may directly or indirectly lead to contaminated watersheds with potential human infective cysts and oocysts. Direct contact with infected animals as cattle or sheep involves a risk of acquiring cryptosporidiosis. Cryptosporidium parvum oocysts excreted from grazing animals or presence in manure run-off close to water-sources used for drinking water production may constitute a risk for waterborne outbreaks of cryptosporidiosis. For Giardia the role of cattle and other grazing animals in the further transmission to humans is not as clear even though cattle also often are infected by human-pathogenic species of Giardia.

Assemblage A and B are the Giardia intestinalis genotypes that infect humans but the zoonotical relevance of these genotypes are still not clear. Dogs and cats are often infected by G. intestinalis. In Australia the genotypes A and C were equally common in dogs (Thompson 1999). G. intestinalis has also been shown to be common in dogs in other countries (Thompson and Robertson 2003). Most cattle are infected by G. intestinalis type E. In a study by Appelbe et al. (2003) it was shown that $<20 \%$ 
of the investigated cattle in Canada and Australia were of the zoonotic assamblage A. However it has been shown that cattle injected with the human genotype get infected (Xiao 1994) and that cattle may play a role in zoonotical transmission of Giardia.

The subgenotypes AI and AII of G.intestinalis were found in horses from Australia and USA (Traub et al. 2005) and horses may constitute a potential source for human infections. Giardia and Cryptosporidium commonly infect sheep. Ryan et al. (2005) showed that 44\% (Giardia) and $26 \%$ (Cryptosporidium) of investigaded sheeps in Australia were infected. Most Giardia spp were not commonly found in humans and the authors suggest that the public health risk of sheep-derived Giardia may be overestimated, which is supported by other authors (Elliot et al. 2005). In an Italian study Giardia intestinalis assamblage A I was found in investigated sheeps $(1,5 \%)$ in Italy and those sheeps may play a role in the zoonotical transmission of human infective Giardia genotypes (Giangaspero et al. 2005). Giardiasis has been referred to as "beaver feaver" in USA; a disease thought to be transmitted from infected beavers to watersheds used for drinking water by bypassing trekkers. Zoonotic gentotypes have also been identified in beavers (Appelbee et al. 2002, Trout 2003).

Few investigations regarding the occurrence of Giardia or Cryptosporidium have been directed towards wild animals in the Nordic countries. Kemper et al. (2004) investigated Norwegian moose, but did not find any occurrence of Cryptosporidium. In a Finnish study, Laakkonen et al. (1994) frequently found Cryptosporidium oocysts in different species of rodents, but no species differentiation was reported from the investigation.

Cattle are thought to be the most common source of transmission to humans of Cryptosporidium. Cryptosporidium is considered to be the most common enteropathogen in calves during their first week of life (O'Handley et al. 1999) and causes diarrhoea, depression, aneroxia and abdominal pain. Cryptosporidium have shown to be common in cattle in both Denmark and Sweden. Björkman et al. (2003) detected Giardia in $29 \%$ and Cryptosporidium in 11\% of calves with diarrhoea in a Swedish study. In Denmark, Enemark et al (2002) found that both C. andersoni (19\%) and the human-pathogenic C. parvum (4,2\%) occurred in a Danish cattle heard.

C. parvum are responsible for infections in sheep and goats and large amounts of oocysts $\left(10^{8}-10^{10}\right.$ oocysts/g faeces) are excreted from infected animals. It is belived that $C$. andersoni does not infect sheep and are unique to cattle. C. suis and C. parvum infect pigs, which also experimentally can be infected with C. hominis (Ryan et al. 2004). Horses are typically asymptomatically infected by $C$. parvum and no hostspecific Cryptosporidium are connected to horses.

C. melagridis has been found in humans, but in lower frequency than C. parvum and C. hominis. C. melagridis infects poultry and are usually 
asymptomatic in chickens but may lead to diarrhoea in turkeys. C. melagridis isolated from a human was infective to chickens mice, piglets as well as calves (Akiyoshi et al. 2004).

Host-specific species, C. canis for dogs and C. felis for cats are occurr, also very rarely infect humans. Infected dogs are often asymptomatic (Irwin 2002) and puppets are more often infected. Cryptosporidium also infect a number of reptilian, C. serpentis, and C. nasorum or fish species C. molnari.

Since cysts and oocysts of Giardia and Cryptosporidium are not fully reduced in the sewage treatment (see Chapter 2), Clams, oysters and other filter feeders may concentrate these organisms to a large extent. Considerable levels of (oo)cysts have been found in these organisms often served and eaten raw, with a corresponding risk of getting infected by these protozoans. The concentrations of Giardia and/or Cryptosporidium found in mussels were also shown to correlate with the concentration of the parasites in the water (Grazyk et al 2002). In a study with molluscs collected from Spain, Italy and England Cryptosporidium $s p$ were present in all the molluscan species aimed for human consumption (Freire-Santos et al 2000). Clams in North America contained Giardia of the assamblage A type, and were probably contaminated by human feaces and thought to be of public health importance (Graczyk et al. 1999). In a Finnish study Rimhannen et al (2005) detected Giardia and Cryptosporidium at all sampling points from river water as well as in mussel A. piscinalis living in the water. 


\section{Giardia and Cryptosporidium in Wastewater and Sewage Sludge}

\subsection{Treatment of wastewater}

The occurrence of infections in a population will be reflected by the presence of the infectious agents in the wastewater generated from the population. Generally, a large sewage system will result in the continuous presence of most pathogens in the wastewater. Wastewater from a smaller system may be free of pathogens during periods, but may, on the other hand, contain higher densities of a specific pathogen during incidences of individuals with infections or during outbreak situations.

Wastewater treatment as such is not optimized for pathogen removal, but rather for removal of phosphorous, nitrogen, suspended solids and BOD. In Sweden and the other Nordic countries there are no official regulated levels regarding the content of pathogenic microorganisms or microbial indicators for outlets from sewage treatment plants to surface waters. In other parts of the world, e.g. in the USA, disinfection is often applied before the wastewater is discharged into a recipient. In Scandinavia with abundance of surface water available, the wastewater recipients and the raw water intakes can often be selected and represent different water bodies. Special precautions may be necessary if the outlet is located close to a recreational site where swimming or other water related activities might take place. In these situations additional precautions related to wastewater treatment may be needed.

Workers at sewage treatment plants may be exposed to various pathogens by direct contact with the wastewater or through splashes or aerosols. Within this working environment there should be an awareness regarding these risk and routines such as protective clothing, wearing mouth protection and thorough hand washing will reduce the risks. In Sweden there is a specific regulation regarding work in sewage treatment plants (AFS 1984:15), which includes requirements for wearing gloves, access to handwashing facilities and vaccination (the later not relevant in this context). A new legislation regarding microbiological risks in the work environment (AFS 2005:1) may be a further guide in how to manage such risks. This legislation is partly reflecting the European legislation regarding biological agents at work (2000/54/EG).

An indirect way of assessing the load of parasites whithin the society is to measure the levels of pathogens in the raw sewage. The load of 
Giardia cysts entering sewage treatment plants is comparatively high in Sweden; levels of approximately 4,000 cysts/L have been found (Ottoson et al. 2006). Cryptosporidium oocysts have been detected in lower concentrations, indicating that cryptosporidiosis may be less prevalent than giardiasis (symptomatic or asymptomatic) whithin the society. Higher densities of Giardia than Cryptosporidium in the raw sewage water have also been detected in other investigations i e in Italy (Caccio et al. 2003).

\subsection{Treatment of sewage sludge}

During wastewater treatment, sludge will be generated from several of the treatment steps. Part of the microorganisms (including pathogens) will attach to particles and end up in the sewage sludge. The sludge is subjected to treatment in order to reduce the volume and to stabilise the material (degradation of easily metabolised organic material). Recently the reduction of pathogens has come into focus, and treatments are now considered more or less necessary also to "hygienise", or sanitise, the sludge. Stabilisation and hygienisation may be achieved in one single process or by a combination of processes. The stabilisation will reduce the smell, which is beneficial also from a hygienic point of view since it reduces the vector attraction (e.g. the attraction of birds, rodents and other possible vectors for disease transmission).

Treatment of sludge is effective as a first barrier to prevent disease transmission. In addition the risks will be minimised if sludge is applied as a fertiliser to arable land by using appropriate application methods that minimise exposure and by appropriate crop selection. The effect of a treatment method can be established by measuring the reduction of various microorganisms or indirectly by measuring the concentration of indicator organisms. Quality controls may also include direct analyses for the detection of various pathogens.

There are several sludge treatment methods. Depending on their operation, they can reduce the pathogen levels in sludge to an acceptable low risk level. Assessment of different methods, as presented in the literature, shows large variations in the reduction of different groups of pathogens. Treatment methods for sludge and other organic wastes with the purpose to sanitise (hygienise) the material are often based on an increase in temperature to levels that will cause inactivation of most pathogenic microorganisms (dependent on exposure time). In several studies it has been shown that thermophilic temperatures will result in a good reduction or in elimination of pathogenic microorganisms whereas it is less possible to achieve appropriate reductions through mesophilic (around $35^{\circ} \mathrm{C}$ ) sludge treatments. Anaerobic digestion and composting will also result in a stabilisation of the sludge, whereas this is not the case when pasteurisation (a high raise in temperature during a short time, e.g. $70^{\circ} \mathrm{C}$ for one 
hour) is applied. In the later case it is necessary to have an additional step for sludge stabilisation. Thermal drying and incineration are other high temperature treatments that will result in both hygienisation and stabilisation.

In addition to temperature treatment, by anaerobic digestion, composting or incineration, lime treatment may be applied as a hygienisation step. By lime treatment it is the raise in $\mathrm{pH}$ (slaked lime) or the raise in $\mathrm{pH}$ in combination with a raise in temperature (quick lime) that causes the hygienisation and stabilisation. $\mathrm{A} \mathrm{pH}$ around 12 has proven necessary to reach acceptable results (in short time treatment). During long-time storage of sludge it is only the ambient parameters that affect pathogen inactivation and these in combination with time govern the reduction. Reinfection and regrowth of pathogens in sludge are relatively common problems. Routines for handling and to control that all material is exposed to sufficiently high temperatures or $\mathrm{pH}$ are therefore essential. The most common method to treat sewage sludge at larger treatment plants in the Nordic countries is by mesophilic digestion, which generally will be followed by centrifugation to decrease the water content. Since discussions of upgrading mesophilic plants to thermophilic are on-going the choice was to focus on temperature as the inactivating parameter in this study.

\subsection{Sludge legislation}

Due to the increased attention of hygienic risks related to sludge, a proposal from the Swedish EPA regarding stricter regulations for sewage sludge is about to be adopted. The present legislation (SNFS 1994:2) does not identify specific treatment demands of sludge, but includes a general statment that biological, thermal or chemical treatement, long time storage or other treatment should be applied to significantly reduce health risks related to use. Furthermore it includes restrictions on use, where sludge application is not allowed on grazing land or on certain crops without a specific time period between the application and use. This legislation is an interpretation of the current EG-directive (86/278/EEG).

The other Nordic countries generally have more defined regulations than Sweden, which also implies stricter regulations on treatments, quality and restrictions for sludge use. Denmark defines different levels on treatments and combines these with quality criteria and restrictions for use. In Norway only quality criteria are defined. In Finland no untreated sludge is allowed for use and mesophilic anaerobic digestion and lime stabilisation are given as examples for treatment. Restrictions for use, but no demands for microbial analysis, are included. USA has complex regulations that, as the EG-proposal (see below), are based on two quality 
classes. A number of treatment alternatives are stated and it is required that they also reduce vector attraction.

The new Swedish proposal contains a list of defined treatments divided into three classes (A, B and $\mathrm{C}$ ), where the division is dependent on the efficiency of the method and the possibility to control the process $(\mathrm{NV}, 2002)$. Each class is related to different restrictions on how to use the sludge. Some quality control parameters regarding Salmonella (a pathogen of concern and an indicator of regrowth) and faecal indicators are also included. Two important statements in the proposal are; (1) that no untreated sludge is allowed for application to land, and (2) that other land than agricultural is included. Sludge use in forests is also specifically mentioned. Apart from sewage sludge, other types of toilet waste fractions are included.

Within the European Union a new sludge-legislation has been discussed for several years but has been postponed for some time. It may be a part of a forthcoming strategic initiative for waste that is planned for 2006. The $3^{\text {rd }}$ draft (2000) for a new EG-directive contained alternatives for treatment in combination with quality demands. A report (EC, 2001) that evaluated this draft suggested modifications for different alternatives for advanced treatments and also defined conventional treatments. Furthermore, the quality monitoring parameters, e.g. which type of microorganisms that should be analysed to assure sufficient treatment, have been discussed. If a new EG-directive is adopted, Denmark, Finland and Sweden, as member states will have to incorporate this legislation as well, and are not allowed to have less strict rules. Norway is also bound to European rules, and would have to implement a new directive. At present, their national legislation is more inspired by the US EPA rules, at least when it comes to quality control.

In both USA and Norway helminth (or parasite) eggs is included as a "theoretical" quality indicator. It is however recognised that these types of parasites are uncommon in developed countries and the absence of eggs (ova) does not necessarily mean that an efficient reduction has occurred. In Norway the relevance in relation to monitoring has been discussed, since only one laboratory in the country is able to perform the analysis (Nygård et al. 2003). Validation of methods is considered more appropriate, and if a method has been proven to remove parasite eggs, monitoring is not necessary (Paulsrud et al. 2004). A comparison with the legislation regarding animal by-products and manure can also be done. Recently broader suggestions for the selection of microorganisms for validation of treatment methods (other than those defined) have been brought forward. In working documents from the EC it is suggested that a $5 \log _{10}$ reduction of bacteria (Enterococcus faecalis), a $3 \log _{10}$ reduction of viruses and a $3 \log _{10}$ reduction of parasites should be required for approval of the treatment method. A further definition of parasites and other organisms is not included, and viability methods are not mentioned. For 
protozoa such as Giardia and Cryptosporidium as well as for other parasites, methods rely on microscopy and when viability is accounted for, a maximum reduction of around $3 \log _{10}(99.9 \%$, counting 1 viable organism out of 1000 is achievable in practical monitoring. The suggested reduction of indicator bacteria was $2 \log _{10}$ for conventional treatments and 4 or $6 \log _{10}$ for advanced treatments (EC 2000; EC 2001). In the Swedish proposal, demands on reduction are not included due to e.g. concern regarding analytical difficulties. Approval of treatment methods other than the ones included in the defined list could however probably be facilitated by validation of the reduction of various groups of microorganisms.

Differences between the European and the Swedish drafts include details in treatment methods that sludge should not be used on vegetables and that sludge can be used on forestland in Sweden. Animal health is more emphasized in Sweden than within EU, and longer time periods between sludge application and grazing are suggested in Sweden, both to protect the animals and since a good animal health will reflect a good situation when it comes to human health.

\subsection{Occurrence and removal of protozoan parasites in sewage treatment systems}

The occurrence of protozoa in wastewater has been studied internationally as well as in Sweden, Norway and Finland but to a lesser extent in Denmark

Reductions have also been estimated by comparing densities in outgoing (treated) wastewater with densities in raw sewage. The reduction of protozoa is probably mainly a result of removal by e.g. sedimentation processes, and to some degree by actual inactivation. In one laboratory study, it was concluded that the ability of primary sewage sedimentation to remove oocyst was poor (Withemore and Robertson 1995). Other relevant studies on occurrence and reduction are presented in table 1. Few of these have accounted for the viability and thus the reduction is either due to removal or due to inactivation that has resulted in disintegration of cysts and oocysts.

Giardia cysts and Cryptosporidium oocysts are frequently detected in raw sewage. Giardia cysts are typically detected in higher numbers than Cryptosporidium oocysts (see table 1). This situation is also reflected in a Swedish study (Ottoson et al 2004) as well as in Norway (Robertson et al. 2006). 
Table 1. Examples of occurrence and reduction of Giardia and Cryptosporidium in different wastewater treatment

\begin{tabular}{|c|c|c|c|c|c|}
\hline Organism & Country & $\begin{array}{l}\text { Untreated wastewater } \\
\text { Concentration of (oo) cysts }\end{array}$ & Treated wastewater & Reduction & Reference \\
\hline $\begin{array}{l}\text { Cryptosp. } \\
\text { Giardia }\end{array}$ & Canada & $\begin{array}{l}\text { mean } 2.6 / \mathrm{L} \\
\text { mean } 1550 \mathrm{~L}\end{array}$ & $\begin{array}{l}\text { mean 10/L } \\
\text { mean 349/L }\end{array}$ & $\begin{array}{l}27 \% \\
76 \%\end{array}$ & Payment et al 2001 \\
\hline $\begin{array}{l}\text { Cryptosp. } \\
\text { Giardia }\end{array}$ & USA & $\begin{array}{l}1500 / L \\
13000 / L\end{array}$ & & & Mayer et al. 1996 \\
\hline $\begin{array}{l}\text { Cryptosp } \\
\text { Giardia }\end{array}$ & Scotland & $\begin{array}{l}0-400 / \mathrm{L} \\
1100-3600 / \mathrm{L}\end{array}$ & $\begin{array}{l}0-1000 / L \\
0-15000 / L\end{array}$ & $\begin{array}{l}15-52 \% \\
48-80 \%\end{array}$ & Robertson et al. $2000^{a}$ \\
\hline $\begin{array}{l}\text { Cryptosp. } \\
\text { Giardia }\end{array}$ & Canada & $\begin{array}{l}4770 / \mathrm{L} \\
8250 / \mathrm{L}\end{array}$ & $\begin{array}{l}5.32 / \mathrm{L} \\
329 / \mathrm{L}\end{array}$ & $\begin{array}{l}2.96 \log _{10} \\
1.40 \log _{10}\end{array}$ & Chauret et al. 1999 \\
\hline $\begin{array}{l}\text { Cryptosp. } \\
\text { Giardia }\end{array}$ & Italy & $\begin{array}{l}25-277 / L \\
2100 / L-420000 / L\end{array}$ & & $87.0-98.4 \%$ & Caccio et al. 2003 \\
\hline $\begin{array}{l}\text { Cryptosp } \\
\text { Giardia }\end{array}$ & Sweden & $\begin{array}{l}22 / L \\
7380 / L\end{array}$ & $\begin{array}{l}2.0 / \mathrm{L} \\
2.0 . / \mathrm{L}\end{array}$ & $\begin{array}{l}1.59 \log _{10} \\
2.63 \log _{10}\end{array}$ & Ottoson et al. 2004 \\
\hline $\begin{array}{l}\text { Cryptosp } \\
\text { Giardia }\end{array}$ & Norway & $\begin{array}{l}485 \text { and } 3145 / \mathrm{L} \\
3420 \text { and } 9520 / \mathrm{L}\end{array}$ & $\begin{array}{l}230 \text { and } 3300 / \mathrm{L} \\
480 \text { and } 5880 / \mathrm{L}\end{array}$ & $\begin{array}{l}0-50 \% \\
0-95 \%\end{array}$ & Robertson et al. $2006^{b}$ \\
\hline
\end{tabular}

IFL= Immunofluorescent antibodies. IMS= Immunomagnetic Separation ${ }^{a}$ Centrifugation with no purification step ${ }^{\mathrm{b}}$ Mean concentration from 3 different STW with two concentration methods.

The inactivation of Cryptospridium, that is considered more robust than Giardia, has been shown to be rapid also by mesophilic digestion of sludge (see table 2: Horan et al. 2002; Stadterman et al. 1995). According to US EPA, the reduction after mesophilic treatment is not sufficient to correspond to their highest class of treated sludge, and concern for survival of protozoa at $35^{\circ} \mathrm{C}$ has been reported (EPA, 1999). Cryptosporidium has been reported to survive at least for 30 days in soil fertilised with sludge (Withemore and Robertson 1995).

Results from studies on survival in sludge are summarised in table 2. For comparison, survival in water at similar temperatures has also been included. In an Australian study the number of Giardia cysts was not reduced during storage. The method applied did not differentiate between viable and dead oocysts (Gibbs et al. 1995). Different studies are partly contradicting each other in relation to reduction and/or resistance, as is evident from the citerd references below. A study performed in the UK (Horan et al. 2002) showed that pathogenic bacteria and poliovirus was sensitive to $\mathrm{pH} 12$ with total inactivation after 2 hours (corresponding to 4.5-7.1 $\log _{10}$ reduction). Cryptosporidium oocysts were however only reduced by $2 \log _{10}$ in one experiment and not at all in another. Horan et al. (2002) also investigated the inactivation during mesophilic anaerobic digestion (MAD) at $35^{\circ} \mathrm{C}$ during 12 days. Bacteria was reduced between 0.4-4.3 $\log _{10}$, where Campylobacter jejuni had the lowest reduction and Salmonella senftenberg the highest. Poliovirus was inactivated rapidly and in total reduced by $6.2 \log _{10}$ during 12 days. Cryptosporidium oocysts were inactivated to below the detection limit. Stadterman et al. (1995) showed a $99.9 \%$ inactivation of Cryptosporidium oocysts after 24 hours of anaerobic digestion at $37^{\circ} \mathrm{C}$. In a study by Withemore and Robertson 
(1995) $10 \%$ of oocysts were still viable after 18 days in mesophilic digestion, whereas thermophilic temperatures $\left(55^{\circ} \mathrm{C}\right)$ in aerobic treatment and pasteurisation were effective for inactivating oocysts.

From the UK it is reported that all analysed types of bacteria and poliovirus was inactivated by pasteurisation at $70^{\circ} \mathrm{C}$ during 30 minutes, which corresponded to a reduction of 5-9 $\log _{10}$ (Horan et al. 2002). In this study viable oocysts were detected after pasteurisation, but they were fully reduced during the subsequent digestion. For Cryptosporidium oocysts it is not possible to measure such high reductions with the prevailing analytical methods

Table 2:Inactivation of Cryptosporidium and Giardia in sludge and in water

\begin{tabular}{|c|c|c|c|c|c|}
\hline Organism & Matrix type & Temperature & Reduction & Method used/viability & Reference \\
\hline C. parvum & $\begin{array}{l}\text { Anaerobic } \\
\text { sludge and } \\
\text { Aerobic } \\
\text { sludge }\end{array}$ & $\begin{array}{l}37^{\circ} \mathrm{C} \\
47^{\circ} \mathrm{C} \\
55^{\circ} \mathrm{C}\end{array}$ & $\begin{array}{l}>99 \% 10 \text { days } \\
>99 \% 4 \text { days } \\
>99 \% 2 \text { days }\end{array}$ & $\mathrm{PI}$ & Kato et al. 2003 \\
\hline C. parvum & Sludge & $\mathrm{AD} 35^{\circ} \mathrm{C}$ & $\begin{array}{l}\text { Below detection } \\
\text { limit after } 12 \\
\text { days }\end{array}$ & $\mathrm{PI} / \mathrm{DAPI}$ & Horan et al. 2002 \\
\hline C. parvum & Sludge & $70^{\circ} \mathrm{C}$ & $\begin{array}{l}\text { Viable oocysts } \\
\text { detected after } 30 \\
\text { minutes }\end{array}$ & PI/DAPI & Horan et al. 2002 \\
\hline C. parvum & Sludge & $\mathrm{AD} 37^{\circ} \mathrm{C}$ & $\begin{array}{l}99.9 \% \text { reduction } \\
\text { after } 24 \text { hours }\end{array}$ & $\mathrm{PI} / \mathrm{DAPI}$ & $\begin{array}{l}\text { Stadterman et al. } \\
1995\end{array}$ \\
\hline C. parvum & Sludge & $35^{\circ} \mathrm{C}$ & $\begin{array}{l}\text { 10\% viable } 18 \\
\text { days }\end{array}$ & $\mathrm{PI} / \mathrm{DAPI}$ & $\begin{array}{l}\text { Whitmore and } \\
\text { Robertson } 1995\end{array}$ \\
\hline C. parvum & Water & $35^{\circ} \mathrm{C}$ & $\begin{array}{l}20 \% \text { infectious } \\
\text { after } 7 \text { days }\end{array}$ & Mouse infectivity & Fayer et al. 1994 \\
\hline C.parvum & Water & $59.7^{\circ} \mathrm{C}$ & $\begin{array}{l}5 \text { min } 1 / 6 \\
\text { mouses infected }\end{array}$ & $\begin{array}{l}\text { Balb mouse infectiv- } \\
\text { ity }\end{array}$ & Fayer et al 1998 \\
\hline $\begin{array}{l}\text { C. parvum } \\
\text { Giardia }\end{array}$ & Sludge & $35^{\circ} \mathrm{C}$ & $\begin{array}{l}0.30 \log _{10} \text { in } 14 \\
\text { days } \\
\text { no reduction }\end{array}$ & $\begin{array}{l}\text { No viability method } \\
\text { used }^{\mathrm{a}}\end{array}$ & Chauret et al. 1999 \\
\hline Giardia. & Sludge & Storage & No reduction & $\begin{array}{l}\text { No viability method } \\
\text { used }\end{array}$ & Gibbs et al. 1995 \\
\hline
\end{tabular}

$\mathrm{AD}=$ anaerobic digestion

${ }^{\text {a }}$ No vital staining done since to high background fluorescence produced

Among the parasites, inactivation of ova from the helminth Ascaris has been evaluated during storage of sludge and showed to be persistent in the Swedish/Nordic climate with survival over a year at $7-21^{\circ} \mathrm{C}$ (Paulsrud et al. 2004).

As stated validation monitoring to assess the reduction efficiency of a treatment or a treatment step, can be part of a quality control of the treated sludge in the operational management in relation to microbial risks. There is however no full consensus related to the choice of organisms to monitor. A routine analysis should preferably be easy to perform, affordable and based on organisms that are endogenous to the material and present in high numbers. In verification monitoring the goal is also to demonstrate a significant reduction. Often faecal indicator bacteria have 
been the organisms of choice in regulatory proposals (EC 2000; EC 2001; Swedish EPA 2002). Alternatively Salmonella has been suggested, due to it large implications on animal health and since it can regrow in the treated material. The above organisms will however not reflect the reduction of Giardia and Cryptosporidium. Another option is to base the monitoring on the inactivation of particularly persistent (hardy) organisms, then ensuring that other pathogens as well will be reduced even more and that the material will be safe to use. When it comes to validate a treatment method, i.e. to evaluate its performance, a wider range of microorganisms including pathogens may be considered. Experience from the present study may in the future be applied to suggested methods and as an input to future legislation.

\subsection{Risks connected with protozoan parasites in wastewater and sludge}

The assessed microbial risks to related to exposure and transmission of infectious diseases are poorly investigated for the handling and use of sewage sludge. In a review it is stated that evidence are lacking that treated sludge causes disease as well as that it does not cause disease (NRC 2002). The conclusion from the NRC was that sophisticated risk assessments and further epidemiological studies are needed. Our view is that the lack of epidemiological evidence connected to sludge use does not imply that the handling and use as a fertiliser is free of risks, since such relations will be difficult to detect.

Protozoan parasites is one of the pathogenic groups of concern and, as stated above, waste products such as sludge will constitute a risk during handling and the subsequent use. How these risks are viewed may differ both in respect of the treatment barrier efficiency as well as in the subsequent exposure of humans and animals. In the European drafts the advanced treatments were considered to reduce pathogens to insignificant levels, whereas risks related to sludge that had been subjected to conventional treatments had to be further reduced by other measures such as suitable areas for use and fertilising techniques, and by relying on further reduction after application to soil. Since both Giardia and Cryptosporidium are zoonotic agents the use of sludge containing cysts and/or oocysts on agricultural land will constitute a risk for wild and domestic animals in the vicinity. In Sweden, the current proposal for treatment of sludge has included a more stringent look on animal health with e.g. longer time periods between sludge application and grazing, and a general view of that treatment should result in sufficient reduction before application. Still several barriers are preferred that further reduce risks and in order to manage possible (undetected) failures. 
In Australia, Giardia was identified as a risk when using sewage sludge and soil products produced from sludge. Gibbs and Ho (1993) referred to enteric viruses, Salmonella and Giardia as constituting the highest risks in "uncontrolled" use of sewage sludge.

In a risk assessment of the sewage system in Uppsala, Giardia was included as one of the model organisms. Four different system alternatives were evaluated and compared regarding possible risk for infection. Since Giardia is one of the more common enteric infections in the Swedish population estimates of numbers in wastewater and sludge resulted in significant risks for aquiring an infection when being exposed to the sludge during handling at the plant or subsequent use (Kärrman et al. 2005). Risks for rotavirus (the model organism used for enteric viruses) resulted in similar risks, whereas Salmonella was of less importance. The possible impact from the sewage system on the total number of infections in society was calculated to be around $1 \%$ for both Giardia and rotavirus.

A risk assessment of the sewage treatment plant in Hässleholm included exposure to the wastewater that was tertiary treated and polished in a wetland and to the sludge that was subjected to mesophilic digestion and further storage before use on agricultural land (Westrell et al. 2004). The exposures resulting in the highest risks were to droplets and aerosols in the treatment plant and to digested sludge during storage or use. Viruses constituted the highest risk if calculated per exposure but in comparison with other pathogens (excluding EHEC), Cryptosporidium had a significant impact on the incidence of infection in the community. Wearing personal protection equipment could easily reduce the risks from exposure to wastewater and sludge for workers. Further treatment of the sludge by changing from mesophilic to thermophilic digestion, or by prolonging the storage, as well as fencing the storage area were identified as measures to reduce the risks from exposure to sludge.

Another Swedish study included a screening-level risk assessment of various sewage products (Albihn and Stenström 1998). Lime treated sludge was considered to constitute a low risk for disease transmission through use on agricultural land. However, external sludge (from smaller treatment plants and single households) was also delivered to the plant and resulted in a reduction in $\mathrm{pH}$. Calculations for this present management indicated that risks for transmission of EHEC, Taenia and Cryptosporidium to animals, and of viruses to humans, were "high" or "very high".

Gale (2005) quantified the risk from seven different reference (or model) pathogens when using sludge that had been mesophilically digested. Giardia resulted in the highest number of infections when not considering a harvest interval (time between sludge application and harvest). If a 12-month interval with linear inactivation of pathogens in soil was applied, risks were reduced, resulting in at the most one infection by C. parvum every 45 years. 



\section{Giardia and Cryptosporidium in the environment}

\subsection{Occurrence, survival and transmission}

Infected animals or humans can pass up to 10 billions $C$. parvum per gram of feaces (O'Handley RM et al. 1999). From grazing animals or when manure is spread on land, may result in huge amounts of viable oocysts capable of entering water sources used for drinking water production. The protozoan parasites Giardia and Cryptosporidium are frequently detected in water sources all over the world. Surface waters may be contaminated from human derived sewage, animal feaces via run-off from manure and/or sludge on land into source water. Wild animals may also contribute to contamination with human-pathogenic (oo)cysts. Groundwater is also at risk, since if a groundwater gets contaminated the treatments are usually not efficient enough. Cysts and oocysts from effluent sewage may contaminate water used for swimming and thus be ingested by the swimmers. Cysts and oocysts are also able to stay alive for a long time in an aquatic environment. Both cysts and oocysts have also been detected in vegetables used for consumption (from surface water irrigation or sludge/manure fertilisation) and foodborne outbreaks have been documented.

Grazing pasture, manure and insufficiently treated sludge may contain viable (oo)cysts that via run-off could contaminate watersheds. In cow feaces $66 \%$ of Cryptosporidium oocysts were dead within 176 days at ambient temperatures (Robertson et al.1992). The corresponding value for human faeces at $4^{\circ} \mathrm{C}$ was $78 \%$ after 178 days. The die-off rates in sediments seem to be higher than in water. Soil may be an exposure route and act as a reservoir of pathogens. Kato et al. (2004) showed an extended persistance of C. parvum in field soil. After 120 days $10 \%$ of oocysts remained viable as measured with PI-inclusion. Davies et al. (2004) showed that both temperature and soil type are influential factors for Cryptosporidium inactivation, with a high dependance on temperature; especially $35^{\circ} \mathrm{C}$ enhanced inactivation as measured with FISHmethodology.

Wild animals may harbour infectious (oo)cysts. Few studies have been performed about the prevalence of protozoan parasites in wild animals in the Nordic countries. Samples from wild cervids were analysed for Giardia and Cryptosporidium in Norway (Hamnes et al. 2006). Both Giardia and Cryptosporidium were found and especially in mooses (Giardia) and roe deer (Cryptosporidium). However the differentiation 
between human and/or zoonotical genotypes were not investigated in this study. The knowledge about transmission of (oo)cysts from wild animals is not sufficient. It may be that different species of wild animals harbour human pathogenic (oo)cysts transmitted from human or/and animal derived sources and act as reservoars for this organisms. Even flies may act as vector for Cryptosporidium shown by Grazyk et al. (2003).

Both Giardia and Cryptosporidium may also be transmitted into the marine ecosystem. Molluscan acts as filter feeders and may accumulate large amounts of potentially infectious microorganisms. This is of special concern for molluscan species as for example oysters often consumpted raw. Oocysts and cysts have also been identified in molluscan species aimed for human consumption in Spain (Freire-Santon 2000) and in the Netherland (Shetz et al. 2006).

Another environmental possible source of infectious (oo)cysts is through infected food and beverage. Robertson et al. (2001) found Giardia and Cryptosporidium on different vegetables in Norway, where mung bean sprouts were the product that contained the most but (oo)cysts were also found on lettuce, dill and strawberries. In a risk assessment by the same author (Robertson et al. 2005), it was assumed that if 60,000 people in Norway consumed a single serving of bean sprouts per week with the detected concentration of (oo)cysts, it would result in 20 cases of Giardia or Cryptosporidium per 100,000 people.

Recently it has been shown that Cryptosporidium are able to complete their life cycle in a cell-free environment (Hijawi et al. 2004), bringing a new perspective on Cryptosporidium survival.

\subsection{Giardia and Cryptosporidium in surface water used for drinking water production and pathways of (oo)cysts into the environment.}

Both Giardia and Cryptosporidium have often been detected in surface water (LeChevallier et al. 1992, Wallis et al.1996), and occasionally in groundwater, drinking water (LeChevallier et al.1991) and in marine waters (Lipp et al. 2001) worldwide. The correlation between indicator organisms or surrogates and the occurrence of protozoans have been investigated, but up to now no good indicator for the presence of protozoans in water has been identified. However, in some studies an operational correlation between high turbidity and the presence of protozoans in raw waters has been found (LeChevallier et al. 1992).

In the Nordic countries surface water is often used for drinking water production (except in Denmark) and are thus vulnerable to contamination both from wastewater outlets and from surface run-offs. Investigations in the Nordic countries have also shown that Giardia and Cryptosporidium frequently occur in surface water (Robertson L et al. 2001, Hansen and 
Stenström 1998, Horman et al. 2004). Robertson et al. (2001) found Cryptosporidium in $13.5 \%$ and Giardia in $9 \%$ of investigated surface waters in Norway. Low concentration, around 1 oocyst/10 L was typically found. Significant correlation between the occurrence and water turbidity and high numbers of animals was shown, but none between seasonality and the occurrence of protozoans. Horman et al. (2004) investigated lakes and rivers in Finland and found Giardia in $13.7 \%$ and Cryptosporidium in $10.1 \%$ of investigated samples. Also in Sweden Giardia and/or Cryptosporidium were detected in 38\% of investigated surfacewater (Hansen and Stenström 1998). However no identification of the occurring species or genotyping were done in these studies. Hanninen et al. (2005) have investigated the contamination of the Vantaa river basin in Finland by two methods; grab sample and by analysing the river mussel Anadonta piscinalis. Both Giardia and Cryptosporidium were detected at all sampling sites, oocysts more often than cysts in river water, but Giardia was found more often than Crytposporidum in the mussels. They also showed that Cryptosporidium genotype 2 and Giardia assamblage B was the most commonly types found.

Extensive studies in USA and Canada performed during the 90-ies showed a frequent occurrence of both Giardia and Cryptosporidium in surface waters (Le Chevallier et al. 1991). In 97\% of all investigated raw waters Giardia or Cryptosporidium were detected. In another study by the same author treated waters were investigated and Giardia was detected in 17\% of drinking water and Cryptosporidium in 27\% (LeChevallier et al. 1993). Wallis et al. (1996) investigated 1760 samples from raw sewage, raw water, and treated water from 72 municipalities across Canada. Giardia cysts were found in $73 \%$ of raw sewage, in $21 \%$ of raw water samples and in $18.2 \%$ of treated water samples. The corresponding frequencies for Cryptosporidium oocysts were $6.1 \%, 4.5 \%$ and $3.5 \%$ respectively. Giardia cysts were found during all seasons but were more abundant during spring and autumn. Also infectivity was measured and $3 \%$ of the Giardia cysts from raw waters and 17\% from sewage waters were infective. They concluded that Giardia cysts, potentially humaninfective are commonly found but that the viability often is low.

Giardia and Cryptosporidium have also been detected in different water sources in Europe. In a study from Italy Giardia was found more often than Cryptosporidium in freshwater (Briancesco and Bonadonna 2005). In UK, Tickell et al. (2002) investigated the seasonal occurrence in surface water of Cryptosporidium near a farm in UK and found that both the frequency of positive samples and the maximum concentrations were highest during autumn and winter. No correlation was found between oocyst levels and rainfall or when slurry was applied on agricultural land. Seasonality was also an investigated factor in a reservoar watershed (Jellison et al. 2002) were C. parvum was found more often in late autumn/winter/early spring than during the summer period. 
Lakes and reservoairs may be at risk of being contaminated from runoff water especially after heavy rain. Brookes et al. (2004) suggest a risk management framework regarding reservoars and rain events. Davies et al. (2004) looked at the dispersion and transport of Cryptosporidium oocysts from faecal pats during simulated rainfall events and concluded that there is an additional need to account for vegetation coverage as well as slope and rainfall run-off. Vegetated land strips is a way to reduce the impact of land run-off and thus the number of (oo)cysts entering into watersources, which also can be applied between grazing pasture land and water sources. Trask et al. (2004) concluded that VFS (Vegetated Filter Strips) could be a best management practice for controlling C. parvum in surface runoff from animal facilities.

\subsection{The occurrence of (oo)cysts in treated sewage water}

Effluent water from sewage water treatment plants often contain (oo)cysts. Gennaccaro et al. (2003) showed that $40 \%$ of finally disinfected effluent samples contained infectious $C$. parvum oocysts at an average concentration of 7 infectious oocysts per $100 \mathrm{~L}$ of water and also occurred in reclaimed water. Giardia cysts and Cryptosporidium oocysts present in sewage in Nordic countries (Ottoson et al. 2004, RimhannenFinne et al. 2004) will partly, but in lower concentrations, end up in the recipient. As stated above, this was also found by Hanninen et al. (2005). Ottoson et al. (2004) found Giardia and Cryptosporidium present in treated wastewater in Sweden at a mean concentration of 40 cysts/L and 4 oocysts/L, respectively, in 6 Swedish wastewater treatment plants (see table 1 chapter 2.4). Higher concentrations of (oo)cysts was detected in sewage effluent from three STP's in Norway, 230-3,300 Cryptosporidium oocysts/L and 480-5,880 Giardia cysts/L (Robertson et al. 2006).

\subsection{Environmental factors for survival of (oo)cysts}

Giardia and especially Cryptosporidium are able to survive for a long time outside the host but different factors will affect the persistence. Most survival experiments have been performed with Cryptosporidium oocysts, believed to be more resistant against environmental influence factors than Giardia cysts. Desiccation is rapidly affecting the persistance with a fast die-off of (oo)cysts (Robertson et al. 1992) but in a humid environmental the survivability is extended.

The temperature is an important factor for (oo)cyst survival. Higher temperatures are believed to destroy protein compontents in the membrane. King et al. (2005) also showed that environmental temperature controls the Cryptosporidium oocyst metabolic rate. Oocysts are able to 
survive well in the temperature range between $4{ }^{\circ} \mathrm{C}$ and $23{ }^{\circ} \mathrm{C}$ in different kinds of water environments, including seawater. Cryptosporidium oocysts remained infectious in seawater (salinities $\leq 3 \%$ at $10{ }^{\circ} \mathrm{C}$ ) for up to 12 weeks and at $1 \%$ salinity in $20{ }^{\circ} \mathrm{C}$ for 8 weeks. In another study Cryptosporidium oocysts were able to maintain its infectivity for at least a year in simulated seawater at $6-8{ }^{\circ} \mathrm{C}$ (Tamburrini et al. 1999). Survival of (oo)cysts in seawater is important in relation to recreational activities and through consumption of uncooked oysters, clams or mussels. Viable oocysts were found in $34.4 \%$ of cultered shellfish samples with propidium-iodine (PI) as a viability assay (Comez-Couso et al. 2003).

Higher tempertures tend to degrade oocysts faster, but these can be infective up to 12 weeks in $25{ }^{\circ} \mathrm{C}$ water (Fayer et al. 1996). Jenkins et al. (2003) assessed the viability of oocysts in $15{ }^{\circ} \mathrm{C}$ water and found that $C$. parvum oocysts remained infective even after 7 months based on infectivity tests and for 8 months based on FISH-methodology. In the thermophilic temperature range accelarated oocysts degradation occur. Fayer (1994) showed that a fraction of Cryptosporidium oocysts remained infective after $5 \mathrm{~min}$ in $59.7^{\circ} \mathrm{C}$ in water. The same author later showed that 2 out of 10 tested mice produced light infections after ingesting oocysts treated at $35^{\circ} \mathrm{C}$ for a week (Fayer et al. 1998; see table 2).

Temperatures below zero do not kill all oocysts, but snap freezing has shown to substantially reduce oocyst viability (Robertson et al. 1992). Slow freezing, as typically occur in the environment do not inactivate oocysts to the same extent. Fayer and Nerad (1996) investigated developmental stages of Cryptosporidium oocysts in infected BALB mice, as a viability measure, and observed these after oocysts have been stored for up to $168 \mathrm{~h}$ in $-10{ }^{\circ} \mathrm{C}$ and $-5^{\circ} \mathrm{C}$ and even in $-15^{\circ} \mathrm{C}$ after $24 \mathrm{~h}$.

Fewer studies of Giardia survivability in water have been performed although viable Giardia cysts have been detected in both surface water (Lemos et al. 2004) and in sewage effluent water (Quientero-Betancourt et al. 2003).

Thus, both Giardia and Cryptosporidium are able to survive well in a climatic context such as in the Nordic countries even though Robertson et al. (2003) assumed that it is less probable that (oo)cysts exposed to the Norwegian winter will not stay alive. The freeze- thaw cycles were believed to kill most (oo)cysts if they are spread on arable land during autumn. The authors suggest that manure or slurry spread during autumn would ensure that Cryptosporidium or Giardia would be dead by spring. 



\section{Drinking water treatment, outbreaks and methods of detection and viability}

\subsection{Drinking water treatment}

Surface water bodies are more vulnerable to contamination of (oo)cysts than groundwater, although (oo)cysts have been identified in both types of water sources as previously described in this report. Prevention of the transmission of protozoan parasites through drinking water requires a multiple barrier approach; protection of watersheds and adequate treatment steps for the reduction. Hydraulic models of the catchment may be helpful for predicting the (oo)cyst concentration as well as to identify important sources of contamination or environmental events when a spread is more likely to occur. One important aspect of watershed protection is to recognise the potential sources of contamination for the specific water catchment and to prevent the contamination as much as possible. Giardia cysts and Cryptosporidium oocysts may be introduced in a water source via insufficient treated sewage, though treatment of sewage is an important barrier against environmental transmission. Also treatment of slurry before land application will reduce the numbers of viable Cryptosporidium oocysts potentially contamination of water sheds via run-off. As described earlier vegetated strips between grazing pasture and watershed may be used as an additional barrier. Storage in reservoirs can also reduce the concentrations of (oo)cysts as shown by Ketelaars et al. (1995). In the Nordic countries the multiple barrier concept is usally adopted.

Traditional indicator organisms used routinely for investigation of faecal pollution are not indicative for the occurrence of protozoans. Surrogates as sporeforming clostridia with a better survival in water have been suggested mainly as a validation tool for treatment or barrier efficiency, but no correlation have been found between these and the presence of Giardia and/or Cryptosporidium. Turbidity is routinely measured in the drinking water process and may indicate higher amounts of particulate matter although a direct correlation with the presence/absence with Cryptosporidium or/and Giardia has not been proven. Particle counts in the size range of parasitic protozoa has however a good predictive value for the removal of parasitic protozoa (Heinecke and Stenström, 2006). Other fecal indicators like E.coli and enterococci have not been shown to 
be useful indicators of the occurrence of protozoan parasites in the raw water.

Filtration is the main barrier for physical removal of protozoan parasites. However Cryptosporidium oocysts are smaller than Giardia cysts and therefore more difficult to remove by filtration. In USA a $3-\log _{10}$ reduction is required in the drinking water process, a $2-\log _{10}$ reduction is usually required from pre-treatment and filtration process and one $\log _{10}$ from additional desinfection. Rapid sand filtration is therotically capable of removing $3 \log _{10}$ of Cryptosporidium oocysts (Ives 1990). Diatomaceous earth filtration has been reported to remove more than $99 \%$ of Giardia cysts (Jakubowski 1990) and up to 4-6 $\log _{10}$ units of Cryptosporidium under laboratory conditions (Ongerth and Hutton 1997). Coagulation and sedimentation remove protozoan parasites as they attach to particles in the sedimentaion process. In a pilot-scale water treatment process, Hsu and Yeh (2003) compared different treatment processes in their removal of Giardia cysts and Cryptosporidium oocysts. They found that coagulation and sedimentation removed the greatest number of both parasites. Conventional teatment (coagulation, sedimentation and filtration) as well as direct filtration can remove $99 \%$ of the (oo)cysts when the process is functioning well (LeChevallier 1991). During events of backwashing the filters the flush water may contain a high concentration of (oo)cysts. Therefore, backwash water should never be recycled back to the treatment process. Slow sand filtration can efficiently remove (oo)cysts but the efficiency is reduced at lower temperatures. Micro- and ultrafiltration have shown to reduce $99.99 \%$ of (oo)cysts (Jacangelo et al.1991).

C. parvum and C. hominis are resistant to inactivation with chlorine in concentrations used in drinking water disinfection. Oocysts of C. parvum and $C$. hominis are also resistant to inactivation of chlorine or monochlorine, even after long incubation times (Korich et al.1990). Even with a $5.25 \%$ sodium hypochlorite treatement for 2 hours oocysts were able to infect mice (Fayer 1995). Also Giardia is not sensitive to chlorine in the concentrations usually used in drinking water production. Chlorine dioxide is slightly more effective but still requires a high $\mathrm{CT}$ value.

UV and ozone have shown a desinfection potential for killing protozoans. In a study by Zimmer et al. (2003) showed a $1.5 \mathrm{log}$ reduction of C. parvum with low dose of UV, $1 \mathrm{~mJ} / \mathrm{cm}^{2} /$ Clancy et al. (1998) showed that pulsed and advanced UV are much more effective against Cryptosporidium than conventional UV treatment. They obtained $99.98 \%$ inactivation at UV doses as low as $19 \mathrm{~mJ} / \mathrm{cm}^{2}$.

Ozone may function as a desinfectant against (oo)cysts. Finch et al. (1993) showed a $99 \%$ inactivation of C. parvum oocysts after $3.5 \mathrm{mg}$ $\mathrm{min} / \mathrm{L}$ and for Giardia cysts $0.6 \mathrm{mg} \mathrm{min} / \mathrm{L}$. Ozone as disinfection inactivated $2 \log _{10}$ reduction of $C$. parvum at $20^{\circ} \mathrm{C}$, with a concentration of 2 $\mathrm{mg} / \mathrm{L}$ during one minute (Corona-Vaszuuez et al. 2002). Also G. muris 
showed a $2 \log _{10}$ inactivation when exposed to $0.3 \mathrm{mg} / \mathrm{L}$, during 0.25 and 3 min (Haas and Kaymak 2003). Ozone inactivation requires higher concentrations when the temperature is low. The cited reduction values above are performed in the temperature rang between $15-20^{\circ} \mathrm{C}$. Hence the CT values required for inactivation of (oo)cysts are high. In the Nordic countries the water temperature is often lower and may affect the reduction rates.

The removal of Cryptosporidium oocysts and Giardia cysts by treatment processes expressed as $\log _{10}$ values are described under WHO's guidelines for drinking water quality (http:/www.who.int). It is clear that the best removal is achieved in the primary steps. The best removal efficiency for Cryptosporidium and Giardia are in decreasing order (expressed as $\log _{10^{-}}$removal), diatomaceous earth (2-6 $\left.\log _{10}\right)$, membrane (2$\left.>4 \log _{10}\right)$, coagulation/filtration $\left(2-2,5 \log _{10}\right)$, and soil passage $(>2->5$ $\left.\log _{10}\right)$, slow sand filtration $\left(1,2->3,7 \log _{10}\right)$ and rapid sand filtration $(0-1$ $\log _{10}$ ). Disinfection processes have shown a better removal for Giardia than for Cryptospordium. Chlorine, chloramines and chlorine dioxide did not affect Cryptosporidium oocysts, but a $0-2 \log _{10}$ removal of Giardia cysts could be obtained. The corresponding ranges for UV are $0-4 \log _{10}$, and for ozone $0-4 \log _{10}$ for Cryptosporidium oocysts and $1-4 \log _{10}$ for Giardia cysts, respectively.

The importance of a well functional filtration is shown in a recent study where the determinants of the geographical distribution of endemic giardiasis in Canada using a modelling approach (Odoi et al. 2004). Higher incidence rates of giardiasis occurred in areas using surface water and in rural areas. Lower incidence prevailed in areas using filtered water. No significant relationship with chlorination, cattle density or intensity of manure application prevailed.

\subsection{Waterborne and food associated outbreaks of Giardia och Cryptospordium}

Direct exposure to contaminated surface waters, e.g. by swimming in rivers or lakes, may constitute a risk for infection by both Giardia and Cryptosporidium. However, the risk from drinking water due to insufficiently treated raw water is probably the transmission route that has attracted the most attention during the last decades. If there is a treatment failure or malfunctioning treatment there is a risk of viable (oo)cysts entering the drinking water system resulting in possible waterborne outbreaks. This has also been exemplified in the WHO Drinking Water guidelines and expressed as "tolerable risk of infections" as related to the concentration ranges in raw water. 
Both surface and groundwater may be contaminated of (oo)cysts from the environment; from sewage, pasture or wild animals. The main cause of waterborne outbreaks of Giardia seems to be drinking water contaminated by sewage. If water treatment is insufficient or an operational failure occur in the treatment system (oo)cysts may enter the drinking water. Infectious human pathogenic cysts or oocysts may also be present even if no indicator organisms are found or no process parameter deviate from their operational values, indicating a contamination. Transmission of (oo) cysts from different sources and the efficiency of water treatment processes are described in chapters 3.1 and 4.1.

Some outbreaks have also been documented from the Nordic countries. During the autumn of 2004, approximately 1,500 people got ill from Giardia due to contamination of drinking water in Bergen, Norway (Bergen kommune 2005). Insufficiently treated sewage in combination with few and malfunctioning barriers in the drinking water treatment are believed to be the reason for this outbreak.

In a ski-resort in Sweden, Sälen, 1,400 persons got ill after sewage intrusion into the drinking water system, and Giardia (as well as another protozoan parasite Entamoeba histolytica) was found to be one of the infectious agents (Ljungström and Castor 1992). In another waterborne outbreak in Sweden in a small community, Mjövik, in 1982 over 600 persons got ill. At least two agents were believed to have caused this outbreak, of which Giardia was one. Giardia was identified from at least 56 persons (Neringer et al. 1987). Faecal accidents in swimming pools have also caused waterborne outbreaks in Sweden. In Lidingö, outside Stockholm, 1,200 people got cryptosporidiosis after swimming in an outdoor pool during the summer of 2003 (Insulander et al. 2005).

Both Giardia and Cryptosporidium have been identified in samples from different vegetables in Norway and an outbreak of cryptosporidiosis with 81 people infected, possible by contaminted food have been described (Eurosurveillance 2005). Outbreaks caused by protozoan parasites in vegetables and apple ciders have also been reported (Millard et al. 1994).

Craun et al. (2005) reviewed the causes of outbreaks associated with recreational water during 1971-2000 in the United States. In threequarters of the outbreaks bacterial or protozoan etiology was identified. Cryptosporidium was the most frequently identified agent and was the identified cause in $15 \%$ of the outbreaks while in $6 \%$ of the outbreaks Giardia was identified. The outbreaks of Giardia and Cryptosporidium included both recreational surface waters and swimming pools but were mainly associated with treated water in swimming and wading pools. The main source of contamination for recreational waters was the bathers themselves.

The largest known waterborne outbreak of Cryptosporidium occurred in Milwaukee in USA 1993 when 403,000 people got cryptosporidiosis 
from the drinking water. (Mc Kenzie et al. 1994). A contamination of the raw water was the identified reason for this outbreak, and traditional water quality measurements did not sufficiently well predict that a risk where at hand. Another large outbreak occurred in 1987 in Georgia in USA where 13,000 people got cryptosporidiosis from public drinking water (Rose 1988).

Several waterborne outbreaks of cryptosporidiosis and giardiasis have been reported from Great Britain. In England an outbreak associated with disinfected groundwater were reported by Bridgeman et al. (2005). In this case surface run-off from nearby grazing pasture during heavy rainfalls are believed to have caused the contamination. In the UK, West Herfordshier and North London raw water that come from deep chalk boreholes got contaminated under influence of surface water (Smith 1998), resulting in 345 cases of cryptosporidiosis. The list of outbreaks can expand though many waterborne outbreaks have been documented. These are just a short exemplification of the numerous outbreaks that have occurred in the UK and elsewhere in Europe.

\subsection{Detection methods, viability and Infectivity assays}

\section{Detection}

Large volumes for monitoring of (oo)cysts in water are required; 10-100 $\mathrm{L}$ for a raw water and up to 1,000 liters for drinking water. Different filters are generally used for concentration, either in a sealed system or as flatbed filtration. The content of particles are concentrated on the filter, whereafter the (oo)cysts are separated from other debris. The most widely separation method used is IMS (Immuno-Magnetic Separation) in which antibody coated beads binds the (oo)cyst from the water concentrate. The bead- (oo)cyst complexes are then further separated by a magnet and can then be further assayed. Cell sorting flow cytometry has also been using to separate (oo)cysts from other particulate matter. Immunofluorescent antibodies attached to the surface of (oo)cysts in combination with DAPI, a dye that binds to DNA and is visualized under UV-light, are widely used for further microscopic identification of the (oo)cysts. However, even if this combination of methods generally is used for identifying and quantifying Cryptosporidium and Giardia in water and environmental samples it does not distinguish between dead or alive (oo)cysts, and does not determins if the (oo)cysts are human-pathogenic or belong to other species. In USA this method is described as Method 1623 (EPA, Environmental Protection Agency) and include filtration, IMS (Immunomagnetic Separation) and Immunofluorescent identification (IFL). An international ISO-standard is under preperation. 


\section{Infectivity Assays}

Mouse infectivity is often considered to be the "reference method" (or "golden standard") that truly assesses the infectivity of oocysts and cysts. Animal model assays are not suitable to use for routine monitoring or for larger environmental or laboratory experiments. Cell culture FDM (Focus Detection Method) (Slifko et al. 1997) methods have been developed for alternative measurments of infectivity instead of animal models. It has been shown that this method correlate well with infectivity models, but it is not suitable for analysing viability of (oo)cysts in "unclean" environmental samples (such as waste water and sludge samples), since constituents of these may inhibit the culture cells.

\section{Viability Assays}

Viability tests have been used as a more simple way of measuring viable and potentially infective (oo)cysts from the environment. Different methods exist. Excystation was one of the first in vitro methods used. In the excystation the (oo)cysts are triggered to start to develop, i.e. to open up and release their sporozoites. The difference between the viable (open and excysted) and the dead (still closed with no excystation) give a value of the proportion of viable and dead (oo)cysts. However this method is not suitable as a viability measurement when the counts are low, like in most enviromental samples.

The inclusion of propidium-iodine (PI) has been used in several studies of naturally occurring (oo)cysts (Robertson et al. 1992). When the (oo)cyst wall is damaged in some way, PI as a large molecule is able to penetrate the cell wall. This is visualized microscopically as an internal red color. DAPI (4'-6-diamidino-2-phenylindole) has the ability to attach to DNA and is visualised as a clear blue colour when exposed to UVlight. In combination PI - (minus) and DAPI+ (plus) will be regarded as a potentially viable (oo)cyst. In some disinfection studies this method have been shown to overestimate viability. The method has been widely used and is a potential candidate method to measure the viablity in environmental studies and samples.

Fluorescent In Situ Hybridisation (FISH) is the most recent in vitro method developed for assessing viability. It uses fluorescent marked nucleotide probes complemenary to rRNA. The intesity in colour is related to higher amount of rRNA, indicative for viability (Vesey et al. 1998; Dorsch et al. 2001). Jenkins et al. (2003) showed that a good correlation existed between FISH and the cell-culture method for up to 8 months of storage of oocysts, but thereafter the FISH method gave false positive reactions if the cell culture test is taken as "the golden standard". The FISH-method has also been applied in other environmental matrixes, such as soil (Davies et al. 2004). 
Based on the above given reasons, FISH was selected as the method of choice in this sludge study, combined with IMS. The immunomagnetic separation has been showed not to reduce viability (Slifko et al. 2000). Organic matters are known to interfere more with cell culture, which therefore was excluded.

Some unclearity still exists between methods that determine the viability (excystation, FISH and dye exlusion; PI) versus those that assess infectivity (mouse assays, cell-culture). Since the FISH method may give false-positive results for example after prolonged storage (Jenkins et al. 2003) a modification to include an RNAse (enzyme that breaks down excessive RNA) pre treatment step that can reduce the number of falsepositive viable oocysts (Smith et al. 2004). In this study RNAsin and VRC to inactivate residual RNAse was included to overcome these shortcomings. 



\section{Material and Methods}

\subsection{Sewage Treatment Plants, STPs}

The sewage treatment plants (STPs) in this investigation were chosen to reflect two different sewage sludge processes, either mesophilic as in Henriksdal, Stockholm, or thermophilic as in Tegelviken, Kalmar. The thermophilic treatment was run at $49.5^{\circ} \mathrm{C}$ for 14 days (mean retention time), while the corresponding mesophilic treatment was run at $35-37{ }^{\circ} \mathrm{C}$ for 21 days (mean retention time). Henriksdals SWTP, connects 641,000 people and Tegelviken 52,000 people. The sewage sludge treatments were run with continously operation.

Tabel 3: Sewage Water Treatment Plants

\begin{tabular}{llll}
\hline & People connected & Sludge treatment & Mean retention time \\
\hline Henriksdal SWTP & 641,000 & Mesophilic $35-37^{\circ} \mathrm{C}$ & 21 days \\
Tegelviken SWTP & 52,000 & Termopfilic $49.5^{\circ} \mathrm{C}$ & 14 days \\
\hline
\end{tabular}

\subsection{Field samples}

Samples $(\mathrm{n}=48)$ were collected during March to May 2005, from Henriksdal's STP and Tegelviken's STP on a weekly basis. Sample types were: raw sewage (1L), untreated sludge (approx. $50 \mathrm{~mL}$ ) and treated sludge (approx. $50 \mathrm{~mL}$ ) sampled after anerobic digestion. Samples were collected as grab samples. The wastewater and sludge samples were sent cold by overnight transport to SMI from Kalmar. Sludge from Henriksdal were collected and transported to SMI within the same day. The samples were stored at $4{ }^{\circ} \mathrm{C}$ until analysis. The indicator analyses were performed at the day of arrival and the protozoan analyses within 2 days.

\subsection{Laboratory study/Microbiological analyses}

\section{Waste water samples}

Raw sewage water was concentrated in $2 \times 50 \mathrm{~mL}$ Falcon tubes and centrifuged for 10 minutes at $1,600 \mathrm{~g}$. The supernatant was aspirated and the remaining packed pellet was further analysed with Immunomagnetic Separation (IMS G/C Combo Kit, Dynal Inc, Oslo) with no more than 0.5 $\mathrm{mL}$ packed pellet/IMS-analyse according to the manufactors description. 
The sewage water concentrates were analysed for the presence of Giardia cysts and Cryptosporidium oocysts with immunofluorescent antibodies as described below (under Protozoan analyses).

\section{Sludge samples}

E. coli and Enterococci (faecal streptococci) were analysed as indicators of bacterial occurrence and reduction and Coliphages as a viral indicator. Both E. coli and Feacal Streptococci are routinely used as quality indicators in water analyses and Coliphages in many situations as indicator of viruses. These reflect the human enteric viruses in size and the ability to survive well in the environment and are more simple and cost-effective method than direct analyses of viruses.

Approx. $1 \mathrm{~g}$ (separately weight for DS-calculations) of sludge was added to $20 \mathrm{~mL}$ tubes. The sludge was diluted tenfold with PBS and mixed for 15 seconds. The dilutions were used in the bacterial, coliphage and protozoan analyses and further 10 diluted to suitable concentrations and analysed as described below. Proportions of the dilution was further IMS-treated and either IFL-stained as described below or permiabilised for viability assessment. At least one proportion of the IMS-treated sample were fixed in $50 \%$ ethanol $(95 \%)$ and $50 \%$ PBS, $10 \mathrm{~min}$ in $80{ }^{\circ} \mathrm{C}$ for further FISH-analyse and stored in $-20{ }^{\circ} \mathrm{C}$ until analysis.

\section{Bacterial analysis}

Analyses of E. coli and Enterococci were performed with Colilert 18 and Enterolert (IDEXX, Westbrook) according to the manufacturer's instructions. For E. coli and Enterococci the treated and untreated sludge were appropriately diluted in PBS and added to IDEXX dehydrated media in the sterile jars supplied. The contents of the jars $(100 \mathrm{~mL})$ were poured into sterile Quanti-Tray 2000 trays and heat-sealed. Quanti-Trays for E. coli were incubated according to the manufacturer's instructions at $35 \pm$ $0.5^{\circ} \mathrm{C}$ for 18 hours. After incubation the fluorescing wells $(366 \mathrm{~nm})$ were counted and an MPN table was used to calculate the number of E. coli. Quanti-Trays for Enterococci were incubated at $41 \pm 0.5^{\circ} \mathrm{C}$ for 24 hours and fluorescing $(366 \mathrm{~nm})$ wells counted and the same MPN table was used to calculate the number of Enterococci.

\section{Coliphage analysis}

Somatic Coliphages are bacterial viruses that can infect E. coli. The numbers of somatic coliphages were counted as plaques created in a confluent bacterial layer in soft agar after incubation in $37^{\circ} \mathrm{C}$ for $18 \mathrm{~h}$. Filters $(0.45$ $\mu \mathrm{m}$, Sartorius) were used to reduce the numbers of interferring bacteria. Samples were filtered before the coliphage analyses. About $25 \mu \mathrm{L}$ of $E$. 
coli (ATCC 13706) from an overnight culture were added to $50 \mathrm{~mL}$ of MSB and placed in a shaker in $37{ }^{\circ} \mathrm{C}$ and incubated for three hours. MSA-agar plates with $0.6 \mathrm{~mL}$ of calciumchloride $\left(\mathrm{CaCl}_{2} \mathrm{X} 2 \mathrm{H}_{2} \mathrm{O} 14,6 \mathrm{~g}\right.$ to $100 \mathrm{~mL}$ of distilled water) $/ 100 \mathrm{~mL}$ MSA were shortly dried in a $56^{\circ} \mathrm{C}$ incubator. One $\mathrm{mL}$ of the sample, $1 \mathrm{~mL}$ of the E.coli host strain and 2.5 $\mathrm{mL}$ of soft agar (MSA + MSB 7/3 dilutions) were mixed and poured onto a MSA agar plate. The solution was allowed to solidify and was incubated inverted for $18 \mathrm{~h}$. The numbers of clear plaques were calculated according to:

$$
\frac{\Sigma \mathrm{n}_{1}+\mathrm{n}_{2} \ldots \mathrm{X} 100}{\Sigma \mathrm{V}_{1}+\mathrm{V}_{2}}
$$

$\mathrm{n}=$ plaque on plate

$\mathrm{V}=$ volume in $\mathrm{mL}$ on plate

\section{Protozoan analysis}

Separation with Immunomagnetic beads (G/C Combo; Dynal Inc., Oslo) was performed according to the manufacturer's instruction with no more than $0.5 \mathrm{~mL}$ of packed pellet per analysis. The final volume of $50 \mu \mathrm{L}$ was added on a slide and the $\mathrm{pH}$ adjusted with $1 \mathrm{M} \mathrm{NaOH}$. The samples were air-dried and fixed with methanol. $50 \mu \mathrm{L}$ of $1 / 20$ diluted FITC-labelled monoclonal antibodies (Aqua Glo G/C direct $20 \mathrm{X}$; Waterborne Inc., New Orleans) against Cryptosporidium oocysts and Giardia cysts were added to the slides and incubated in a humidified chamber at $37^{\circ} \mathrm{C}$ for 40 minutes. The antibody solution was aspirated and a drop of 4', 6diamidino-2-phenylindole (DAPI) with a final concentration of $0.4 \mathrm{~g} / \mathrm{ml}^{-1}$ added to the slides and incubated for two minutes at room temperature and then aspirated and rinsed with a drop of distilled water. Mounting media (Waterborne Inc, New Orleans) and a cover glass were added and sealed with nail polish. Microscopic analyses were performed with a Zeiss Axioskop microscope (40 X and $100 \mathrm{X}$ oil objective). A $546 \mathrm{~nm}$ filter for DAPI and 450-490 nm filters for FITC were used. Apple green FITC coloured cysts and oocysts whithin the right size were regarded as Cryptosporidium or Giardia. DAPI inclusion was used as an additional dye.

\section{FISH, Fluorescent in situ hybridisation}

One gram of sludge was seeded with oocysts and run in 2 parallels and added to $1.5 \mathrm{~mL}$ Eppendorf tubes. Deionised water was added up to the top. The tubes were placed in vacuum holders and placed into $10{ }^{\circ} \mathrm{C}, 35$ ${ }^{\circ} \mathrm{C}$ and $50{ }^{\circ} \mathrm{C}$ incubators. The sludge was treated with Immunumagnetic 
Separation (IMS) as for sewage as described above. The remaining $50 \mu 1$ in each tube was neutralized with $5 \mu \mathrm{L}$ of $1 \mathrm{M} \mathrm{NaOH}$. The oocysts were permebilized by adding $50 \%$ ethanol for $10 \mathrm{~min}$ in $80{ }^{\circ} \mathrm{C}$ and were then kept in $20^{\circ} \mathrm{C}$ until analysis. The (oo)cysts were loaded on to membrane filters $(0.8 \mu \mathrm{m}$ pore size, $13 \mathrm{~mm}$ diameter, Millipore) in Swinnex filter housings by filtration. The filters were washed twice by passing thorough $0.5 \mathrm{~mL}$ of PBS containing $1 \mathrm{mmol}^{-1}$ vanadyl ribonucleoside complex (VRC, Sigma) and once with $200 \mu 1$ pre-heated hybridisation buffer $(0,9$ $\mathrm{mol}^{-1} \mathrm{NaCl}, 20 \mathrm{mmol}^{-1}$ Tris-Cl, $0.5 \%$ v/v) SDS. 1 pmol oligonucleotide Cy3 labelled Cry 1-probe was placed on the surface of the membrane filers at a concentration of $1 \mu \mathrm{mol}$ in $200 \mu \mathrm{l}$ of hybridisation buffer. The filter housings were sealed at both ends and incubated in the dark at $42{ }^{\circ} \mathrm{C}$ for $2 \mathrm{~h}$. After incubation, the probe/hybridisation solution was removed by rinsing the membrane twice with $1 \mathrm{~mL}$ of PBS containing $1 \mathrm{mM}$ VRC. (Oo)cysts were stained with $50 \mu \mathrm{l}$ Aqua-Glo, G/C direct antibodies (Waterborne, New Orleans) containing RNAsin (40 units $\mathrm{ml}^{-1}$. After $30 \mathrm{~min}$ at room temperature the membranes were washed with $1 \mathrm{~mL} 1 \mathrm{mmol}^{-1}$ VRC and mounted on microscopic slides. The microscopic analyse was performed with filter for FITC and for CY3. A Ziess microscope with 40 $\mathrm{X}$ oil objectives was used. Oocysts with red dye within were regarded as FISH-positive and potentially viable and oocysts with no CY3 inclusion were regarded as dead.

\section{Recovery tests}

Quality control was performed with Color Seed (BFD, Biotech Frontiers Decisive, North Ryde, Australia) according to the manufacturer's instruction. One hundred Texas red labelled Cryptosporidium oocysts and 100 Giardia cysts were added to the sample and the recovery thus equal to detected number of red labelled (oo)cysts. 


\section{Results}

\subsection{Giardia and Cryptosporidium in sewage and sludge}

Giardia and Cryptosporidium occurrence and viability in the sewage influent water

The concentrations of Giardia and Cryptosporidium in the influent sewage water in Henriksdal and Tegeluddens STP are summarized in table 4. Giardia cysts were detected at all sampling occasions at both plants. In Henriksdal STP the mean concentration of Giardia cysts in the influent sewage was 807 cysts/ $\mathrm{L}$ and the concentration varied between 108-1,370 cysts/L. Lower concentrations of Giardia cysts was detected in sewage water in Tegeluddens STP with a mean concentration of 160 cysts/L (varied between 28-335 cysts/L). Cryptosporidium oocysts were only detected in 3/9 samples from Henriksdal and in 1/4 sample from Tegeludden. The concentration of Cryptosporidium oocysts was also considerable lower than for Giardia cysts and varied between 3-15 oocysts/L of influent sewage. No samples were taken in the effluent sewage after treatment, thus no reduction after sewage treatment was calculated.

Table 4: Concentrations of Cryptosporidium and Giardia in influent sewage water and viability of detected cysts

\begin{tabular}{lrrr}
\hline & $\begin{array}{c}\text { Cryptosporidium/L } \\
\text { Mean oocysts/L (n) }\end{array}$ & $\begin{array}{r}\text { GiardialL } \\
\text { Mean cysts/L (n) }\end{array}$ & $\begin{array}{r}\text { Giardia Cyst Viability } \\
\text { \% Fish + cysts (n) }\end{array}$ \\
\hline Henriksdal STP & $4(9)$ & $807(9)$ & $46.2(4)$ \\
Tegelviken STP & $3(4)$ & $160(4)$ & $16.3(1)$ \\
\hline
\end{tabular}

The concentrated samples were subdivided and a proportion of respective sample were analysed with fluorescent in situ hybridization (FISH) for detection of viable oo(cysts) and summarized in table 4 . The results are expressed as \% viable (oo)cysts/total count of (oo)cysts and not as concentration/L. The Cryptosporidium oocysts were under the detection limit when FISH-methodology was used and no viability measurment in the influent sewage water was possible to perform. All visable Giardia cysts were investigated in each sample preperation and the number of Giardia cysts varied between 1-46 cysts/sample with a mean of 29 cysts/preparation in Henriksdal influent sewage water. The proportion of viable cysts (expressed as FISH-positive cysts/total cysts) varied between $6.8 \%(3 / 33)-100 \%(1 / 1)$ with a mean of 46.2 viable cysts/sample in Henriksdal. In Tegeluddens STP only one sample of influent sewage water 
contained countable amounts of cysts and the viability was $16.3 \%(7 / 43)$ of the observed cysts. These findings indicate that the viability of cysts entering the sewage treatment may vary considerable over time and before settling into the sludge for further treatments.

The occurrence of (oo)cysts in the untreated and treated sludge

The occurrences of Giardia and Cryptosporidium in untreated and treated sludge are summarized in table 6 . The concentrations are expressed as (oo)cysts/g ww (wet weight) and (oo)cysts/g DS (dry solid). Values of DS and $\mathrm{pH}$ are summarized in a separate table; 5 . The recoveries from the sludge samples were measured with Color Seed (100 oocysts +100 cysts) added to the sludge samples. The recoveries were, with IMS/IFLmethodology: (four parallels) Giardia cysts $63 \%$ ( \pm SD 12 ) and Cryptosporidium oocysts $25 \%$ ( \pm SD 4.8 ). The concentrations of (oo)cysts in table $\mathrm{x}$ are adjusted after recoveries.

Tabel 5; DS (Dry solid) and pH values in untreated and treated sludge from the two STP. DS and pH values from Henriksdal's STP are based on mean from a weekly base but fromTegelviken the values are based on the actual samples

\begin{tabular}{lrrrr}
\hline $\begin{array}{l}\text { STP } \\
\text { Treatment }\end{array}$ & $\begin{array}{r}\text { DS \% untreated } \\
\text { sludge mean (min- } \\
\text { max) }\end{array}$ & $\begin{array}{r}\text { pH untreated sludge } \\
\text { mean (min-max) }\end{array}$ & $\begin{array}{r}\text { DS \% treated sludge } \\
\text { mean (min-max) }\end{array}$ & $\begin{array}{r}\text { pH treated sludge } \\
\text { mean (min-max) }\end{array}$ \\
\hline $\begin{array}{l}\text { Henriksdal STP } \\
\text { Mesophilic }\end{array}$ & $3.7(3.4-4.1)$ & n.d & $2.4(2.2-2.8)$ & $7.2(7.0-7.3)$ \\
$\begin{array}{l}\text { Tegelviken STP } \\
\text { Thermophilic }\end{array}$ & $3.5(3.1-4.2)$ & $6.4(6.2-66)$ & $2.1(1.9-2.4)$ & $7.6(7.5-7.7)$ \\
\hline
\end{tabular}

Cryptosporidium oocysts were detected in lower concentrations and at fewer occasions than Giardia cysts as in the influent sewage water. Cryptosporidium oocysts were only detected twice in the raw sludge in samples from Henriksdals STP and never in the treated sludge in neither of the investigated STP's. With a method recovery of $25 \%$ the concentrations of oocysts was calculated to 2 and 6 oocysts/g ww and 36 and 168 oocysts/g DS.

Table 6: Concentrations of Giardia in the untreated and treated sludge at Henriksdal's and Tegelviken's STP. The concentrations are adjusted according to the recovery efficiency

\begin{tabular}{|c|c|c|c|c|}
\hline $\begin{array}{l}\text { STP } \\
\text { Treatment }\end{array}$ & $\begin{array}{r}\text { Untreated sludge } \\
\text { Mean cysts/g ww } \\
\text { (min-max) }\end{array}$ & $\begin{array}{r}\text { Untreated sludge } \\
\text { Mean cysts/g } \\
\text { D.S(min-max) }\end{array}$ & $\begin{array}{r}\text { Treated sludge } \\
\text { Mean cysts g/ww } \\
\text { (min-max) }\end{array}$ & $\begin{array}{r}\text { Treated sludge } \\
\text { Mean cysts /g DS } \\
\text { (min-max) }\end{array}$ \\
\hline $\begin{array}{l}\text { Henriksdal } \\
\text { Mesophilic }\end{array}$ & $\begin{array}{r}474 \\
(207-1,038)\end{array}$ & $\begin{array}{r}13,312 \\
(2,725-30,543)\end{array}$ & $\begin{array}{r}236 \\
(10-625)\end{array}$ & $\begin{array}{r}9,444 \\
(375-26,046)\end{array}$ \\
\hline $\begin{array}{l}\text { Tegelviken } \\
\text { Thermophilic }\end{array}$ & $\begin{array}{r}36 \\
(5-100)\end{array}$ & $\begin{array}{r}992 \\
(189-2,791)\end{array}$ & $\begin{array}{r}95 \\
(48-163)\end{array}$ & $\begin{array}{r}4,673 \\
(2,121-8,582)\end{array}$ \\
\hline
\end{tabular}

Giardia cysts were detected in all sludge samples, (both treated and untreated) at every occasion. The mean concentration of Giardia cysts in 
untreated sludge was one 10-log higher in Henriksdal's STP (474 cysts/g w.w) than in Tegelviken's STP (36 cysts/g ww). Variations in concentration between different sample occasions at the same STP's were sometimes high. Cysts were reduced after treatment in Henriksdals STP, but no reduction in number was observed in Tegelvikens STP. In fact the concentrations were twice as high after treatment than before even after differences in D.S was adjusted. It is not surprising that the variation in (oo)dysts numbers were large since samples were collected as grab samples not in pairs. Giardia cysts were detected in higher concentrations and more frequently than Cryptosporidium in the influent sludge as in the influent sewage water. The mean concentration of cysts in the influent sewage water, approx 160-800/L were concentrated into 36-474 cysts/g of raw sludge. It is likely that most cysts settle in the sludge during the sludge treatment.

\section{Viability measurement of Giardia in untreated and treated sludge}

Measurement of viability was performed in untreated and treated sludge from Henriksdal STP and Tegeludden STP and the results are shown in table 7. No Cryptosporidium were found in the proportions of sludge samples that were hybridizated with probes (FISH), whereby no direct measurment of viability of Cryptosporidium oocysts could be done. Giardia cysts were found in all sludge samples and a FISH viability test could be done in most but not all instances. All visable cysts were investigated in respective sub-samples from the orginal concentrate. Numbers of countable cysts varied in the raw sludge samples from Henriksdal between 3-102 cysts/preparations and from Tegeludden between 3-60 cysts. The proportion of viable cysts is shown in table 7 .

Table 7: Viability measured as proportion of viable cysts (FISH-positive)/total count of cysts in the raw and treated sludge from two Sewage Treatment Plants

\begin{tabular}{lrr}
\hline STP & $\begin{array}{r}\text { Raw sludge } \\
\text { Treatment }\end{array}$ & $\begin{array}{r}\text { Treated sludge } \\
\text { Cyst Viability (\%) } \mathbf{s t d}(\mathbf{n})\end{array}$ \\
\hline $\begin{array}{l}\text { Henriksdal } \\
\text { Mesophilic }\end{array}$ & $17.0 \pm 15.9(5)$ & $1.8 \pm 1.84(6)$ \\
$\begin{array}{l}\text { Tegeludden } \\
\text { Thermophilic }\end{array}$ & $40.5 \pm 1.4(2)$ & $0.8 \pm 1.13(2)$ \\
\hline
\end{tabular}

The reduction in viability was stastistically significant $(\mathrm{P}=0.001)$ based on the pooled numbers of cysts for both STP's (Sigma Stat). Viable cysts were detected in the untreated sludge in both STP's at every sampling occasion however the percentage of viable differed between samples. The mean \% viability was higher in the two samples from Tegeludden's STP than in Henriksdal's STP. The proportion of viable cysts differed between $2.9-41.7 \%$ in the untreated sludge from Henriksdal and $14.3-66.7 \%$ from Tegeludden. A few cysts were still viable after both thermophilic and mesophilic treatment. In Henriksdals STP 1.8\% 9/500 cysts were still 
FISH-positive after a mesophilic treatment with a retention time of 21 days. One single cyst (of 81) was still FISH-positive after the thermophilic treatment in Tegeluddens STP after 14 days of retension. Difficulties in interpretion of FISH-signals were experienced during the microscopic reading of the preparations. High red background in the samples may have interferred, and it is possible that the positive signals were due to this. There is also a possibility that some sludge fractions may not have been exposed to full retention time due to treatment operational factors not investigated further in this study.

\subsection{Cryptosporidium parvum survivability in sludge at different temperatures}

Viable Cryptosporidium parvum oocysts inoculated into sludge samples (duplicates) were incubated in $50^{\circ} \mathrm{C}, 35^{\circ} \mathrm{C}$ and $10{ }^{\circ} \mathrm{C}$ in sealed tubes and in an anaerobic surrounding. The die-off curves for Cryptosporidium oocysts in sludge in $35{ }^{\circ} \mathrm{C}$ and $50{ }^{\circ} \mathrm{C}$ are shown in figure 1 . The initial viability was calculated to $40.5 \%$ based on 4 replications with at least 100 oocysts/replicate investigated.

A.

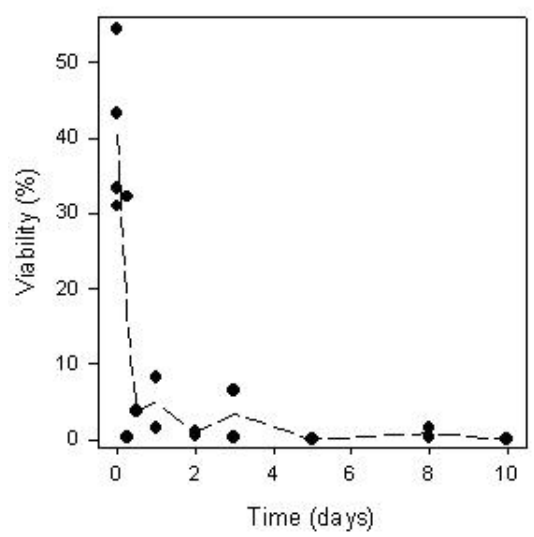

B.

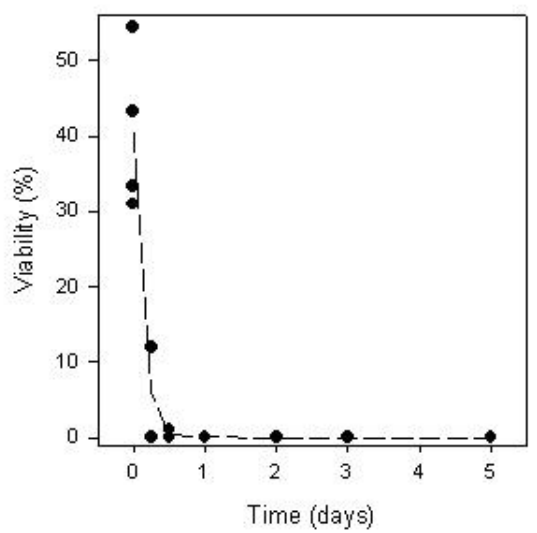

Figure 1: $35{ }^{\circ} \mathrm{C}(\mathrm{A})$ and $50{ }^{\circ} \mathrm{C}(\mathrm{B})$. Mean of duplicate of sampling times drawn in a line.

Duplicates samples were analysed after $6 \mathrm{~h}$ and $12 \mathrm{~h}$ treatment during the first day and then once a day for samples in $35^{\circ} \mathrm{C}$ and $50^{\circ} \mathrm{C}$. At least 100 oocysts were investigated in each duplicate (171-510). A large proportion of the oocysts died during the first $6 \mathrm{~h}$. After $6 \mathrm{~h}$ treatment $16.3 \%$ of the oocysts in $35{ }^{\circ} \mathrm{C}$ were still viable and only $6 \%$ were viable in $50{ }^{\circ} \mathrm{C}$. After an additional $6 \mathrm{~h}$ (total $12 \mathrm{~h}$ ) only $1 \%$ of the oocysts in $50^{\circ} \mathrm{C}$ treatment were viable and $3.7 \%$ in the $35{ }^{\circ} \mathrm{C}$ treatment. After $24 \mathrm{~h}$ only 1 of 747 investigated oocysts were viable in $50{ }^{\circ} \mathrm{C}$ treatment and thereafter no viable oocysts were detected in tubes that had been incubated at this tem- 
perature. In $35^{\circ} \mathrm{C}$ treatment a few oocysts were still viable after 3 days as well as after 8 days but not after that.

Oocysts seeded in sludge and incubated in $10{ }^{\circ} \mathrm{C}$ showed a reduced viability during the first 3 days from $41 \%$ to $14 \%$. Viable oocysts were still detected after 8 and 14 days but no FISH-positive oocysts were seen after an incubation time of 22 days. Large differences in \% viability between duplicates were observed. In a control with pure oocysts in water incubated in $4{ }^{\circ} \mathrm{C}$ FISH-positive oocysts were still detected after 42 days (viability $32 \%$ ) and after 90 days (viability $20 \%$ ).

\subsection{Indicator organisms in the untreated and treated sludge}

The concentrations of indicator organisms in the untreated and treated sludge are shown in table 8 and 9 expressed as CFU (colony forming units) or PFU (plaque forming units) for the Coliphages. Concentrations are based on calculations of CFU or PFU/g ww and CFU/PFU/g DS. Values of DS and $\mathrm{pH}$ are shown previous in table 5.

Table 8. Concentrations of indicator organisms and log10 reduction expressed as CFU or PFU/g ww

\begin{tabular}{llll}
\hline & $\begin{array}{l}\text { Untreated sludge } \\
\text { Mean CFU lg ww } \pm \text { DS (n) }\end{array}$ & $\begin{array}{l}\text { Treated sludge } \\
\text { Mean CFU/g ww } \pm \text { DS (n) }\end{array}$ & Reduction $\log _{10}$ \\
\hline $\begin{array}{l}\text { Henriksdal STP } \\
\text { E. coli }\end{array}$ & $7.2 \times 10^{6} \pm 2.7 \times 10^{6}(9)$ & $9.7 \times 10^{3} \pm 5.3 \times 10^{3}(9)$ & 2.87 \\
Enterococcus & $7.9 \times 10^{4} \pm 3.4 \times 10^{4}(6)$ & $1.6 \times 10^{3} \pm 1.9 \times 10^{3}(7)$ & 1.71 \\
Coliphages & $4.7 \times 10^{4} \pm 1.9 \pm 10^{4}(8)$ & $1.0 \times 10^{4} \pm 2.5 \times 10^{4}(8)$ & 0.67 \\
Tegeviken STP & & & \\
E. coli & $4.4 \times 10^{6} \pm 1.7 \times 10^{6}(6)$ & $1.6 \times 10^{3} \pm 1.7 \times 10^{3}(6)$ & 3.43 \\
Enterococcus & $2.1 \times 10^{4} \pm 1.2 \times 10^{4}(3)$ & $3.4 \times 10^{2} \pm 3.2 \times 10^{2}(3)$ & 1.79 \\
Coliphages & $2.4 \times 10^{4} \pm 6.8 \times 10^{4}(6)$ & $3.7 \times 10^{3} \pm 2.9 \times 10^{3}(6)$ & 0.82 \\
\hline
\end{tabular}


Table 9. Concentration of indicator organisms and log10 reduction expressed as CFU or PFU/g DS

\begin{tabular}{llll}
\hline & $\begin{array}{l}\text { Untreated sludge } \\
\text { Mean CFU/g } \pm \text { DS }(\mathbf{n})\end{array}$ & $\begin{array}{l}\text { Treated sludge } \\
\text { Mean CFU /g DM } \pm \text { DS (n) }\end{array}$ & Reduction log $_{10}$ \\
\hline Henriksdal STP & & & \\
E. coli & $1.9 \times 10^{8} \pm 5.5 \times 10^{7}(9)$ & $4.0 \times 10^{5} \pm 2.2 \times 10^{5}(9)$ & 2.69 \\
Enterococcus & $2.1 \times 10^{6} \pm 1.0 \times 10^{6}(6)$ & $6.2 \times 104 \pm 7.5 \times 10^{4}(7)$ & 1.54 \\
Coliphages & $1.3 \times 10^{6} \pm 5.3 \times 10^{5}(8)$ & $4.1 \times 105 \pm 1.0 \times 10^{6}(8)$ & 0.50 \\
Tegeviken STP & & & \\
E. coli & $1.2 \times 10^{8} \pm 4.0 \times 10^{7}(6)$ & $7.2 \times 10^{4} \pm 8.1 \times 10^{4}(6)$ & 3.24 \\
Enterococcus & $5.5 \times 10^{5} \pm 3.2 \times 10^{5}(3)$ & $5.9 \times 10^{3} \pm 3.7 \times 10^{3}(6)$ & 1.97 \\
Coliphages & $1.7 \times 10^{5} \pm 3.3 \times 10^{5}(6)$ & $1.7 \times 10^{5} \pm 1.4 \times 10^{5}(6)$ & 0.53 \\
\hline
\end{tabular}

E. coli was present in the highest concentration in sludge from both STP's. The concentrations were $7.2 \times 10^{6} / \mathrm{g}$ ww in the raw sludge from Henriksdal and $4.4 \times 10^{6} / \mathrm{g}$ ww from Tegeludden. Enterococcus was present in about $2 \log _{10}$ lower concentrations than E. coli in the untreated sludge; $7.9 \times 10^{4} / \mathrm{g}$ ww (Henriksdal) and $2.1 \times 10^{4} / \mathrm{g}$ ww (Tegeludden). Colphage concentrations were about the same level as fecal enterococcus; $4.7 \times 10^{4} / \mathrm{g}$ ww (Henriksdal) and $2.4 \times 10^{4} / \mathrm{g}$ ww (Tegeludden) of sludge of untreated sludge.

The reduction of E.coli, Enterococcus and Coliphages are calculated as $\log _{10}$ reduction from the mean concentrations and not from paired samples. E.coli, were reduced to a much higher extent than the other indicator organisms. The reduction was highest in the thermophilic treatment (Tegeludden) with a $\log _{10}$-reduction of 3.43 followed by 2.87 in the mesophilic treatment (Henriksdal). The coliphages, as indicator of viruses, reduced to a less extent in the thermophilic than in the mesophilic treatment.

The mean of DS in raw, untreated sludge was 3.7\% in Henriksdal and $3.5 \%$ in Tegeludden and in treated sludge 2.1 och $2.4 \%$. The content of dry matter did not vary considerable between sampling as shown in table 5. Therefore no large differences between reductions when consideration of DS was shown. 


\section{Discussion}

The presence of protozoa in incoming wastewater will result in their presence in sludge. In this study the densities of Cryptosporidium oocysts were very low in the raw wastewater and oocysts could just be recovered from the sludge in a few samples. The densities of Giardia were higher, also reflecting their concentration in the sludge. The risks from e.g. Giardia in sludge have previously been acknowledged although the focus on protozoa has rather been on their occurrence in drinking water and raw water and not on potential sources of contamination. The densities in the different wastewater fractions reflect the incidence in the population and it is clear that wastewater and untreated sludge may pose a risk to exposed individuals in addition to being a source of contamination of surface waters.

Based on the reported laboratory studies the digestion of sludge will significantly reduce the risk where a full inactivation can be reached, both for the mesophilic and the thermophilic processes, within days or weeks. These results obtained in tests with Cryptosporidium are additionally applicable to Giardia since the Giardia cysts are known to generally be less persistent than Cryptosporidium oocysts. The laboratory investigations imply that the risk from exposure to digested sludge in well functioning processes is low or insignificant. In the field samples, a few viable Giardia cysts were found both after mesophilic and thermophilic digestion. The viability measurements performed is more applicable for oocysts than cysts, mainly due to potential false positive results for the latter group. A reduction in viability is generally observed also for Giardia if comparing untreated and treated sludge samples, indicating a significant effect of treatment, which would result in a similar low risk from exposure to sludge as estimated above.

In this study it was shown that Giardia cysts were present in considerably higher mean concentrations ( 800 and 160 cysts/L respectively) than Cryptosporidium oocysts (4 and 3 oocysts/L respectively) in the influent sewage water from two investigated sewage treatment plants. This clearly shows that giardiasis is more frequently occurring in the population contributing to the loads in the STPs investigated in Sweden. Viability measurment with the FISH-methodology showed that around $30 \%$ of cysts entering the sewage treatment were viable. However, the proportion of viable cysts varied between $6.4 \%-100 \%$ on different sample days in Henriksdals STP. These findings indicate that the variability of the water quality related to these organisms as well as the concentrations of (oo)cysts may vary considerably from times to another. Although it was shown that most (oo)cysts are concentrated in the sludge, it has in 
previous studies in Sweden (Ottoson et al. 2004) been shown that densities in effluent sewage are around 4 oocysts/L and 40 cysts/L, respectively. These (oo)cysts may be transmitted to water sources and pose a risk for individuals exposed to recreational water and possibly also from exposure to drinking water due to the exsting (possibly not sufficiently effective) treatment.

It was also shown that Giardia cysts (and Cryptosporidium oocysts) were concentrated and present in high concentrations in the raw untreated sludge in the investigated STPs. The mean concentration of cysts per gram ww was 36 and 474 from Tegelvikens and Henriksdals STP, respectively. The numbers of cysts did not decrease during treatment even when dry matter was considered. Since samples were collected as grab samples it is natural that variations in cyst numbers were large. Difficulty in application of FISH-methodology for Giardia to sludge samples reduced the numbers of cysts to investigate for viability. About $30 \%$ of investigated cysts were regarded as viable (the same $\%$ as in the raw sewage) before sludge treatment (in the raw sludge). The viability was reduced after sludge treatment. However, a few cysts still showed positive FISH-signals after both thermophilic and mesophilic treatment. False positive FISH-signals has been described before and it is believed that these cysts do not represent the actual situation but that their numbers may be affected by the fluorescent signals from other material in the samples, thus affecting the interpretions. It is likely that some sludge fractions were exposed to shorter retention time than the mean time of 14 and 21 days, as the sludge is being mixed continously.

Experimental bench-scale studies under thermophilic $50^{\circ} \mathrm{C}$ and mesophilic $35^{\circ} \mathrm{C}$ sludge treatment conditions with Cryptosporidium resulted in a rapid decrease in viability during the initial phase. The increase in temperature may affect the viability of oocysts drastically as indicated by the shape of the curve in figure 1. An adaptation of the Cryptosporidium oocysts to the experimental conditions in the sludge were made in room temperature for 6 hours before exposure to the higher temperatures, in order to minimize analytical errors. A similar initial die-off was also observed for the experiments performed at $10^{\circ} \mathrm{C}$. It might be that substances/organic material in the sludge affects the viability of the oocysts. From our results and previous studies it is clearly indicated that the reduction in viability of protozoa often is more rapid in sludge than in water. It is believed that different substances present in sludge result in a generally harsher environment than what is prevailing in water. Studies of inactivation in water could however aid in the evaluation of temperature effects on protozoa and as previously shown (see table 2, Fayer) a more rapid inactivation was obtained in $60^{\circ} \mathrm{C}$ than in $35^{\circ} \mathrm{C}$. Full inactivation of oocysts at $50^{\circ} \mathrm{C}$ was achieved after 2 days of incubation and a slightly slower die-off was observed in $35^{\circ} \mathrm{C}$ treatment. This implies that the risk 
from exposure to digested sludge is low or insignificant if the treatment is properly performed.

The results from the experiments at the lower temperature of $10^{\circ} \mathrm{C}$ can be applicable in relation to storage of sludge as a method for treatment. This temperature corresponds to an average temperature in the Nordic climate in many situations. After approximately 3 weeks there were no viable oocysts detected in the sludge samples. Compared to other studies including indicator bacteria, Salmonella and Ascaris (referred to earlier in the report), this survival time is short. The general opinion that Cryptosporidium oocysts are robust organisms does therefore not seem to be appropriate at these environmental conditions. However in this study Cryptosporidium oocysts were still viable after 90 days (22\%) in water solution $\left(4^{\circ} \mathrm{C}\right)$. It is reasonable to assume that factors other than temperature also may affect the (oo)cyst viability.

The reduction of indicator bacteria and coliphages was not higher after thermophilic digestion than after mesophilic digestion, which was unexpected. Even if a slightly higher survival of Cryptosporidium was recorded for the mesophilic temperature $\left(35^{\circ} \mathrm{C}\right)$ than at $55^{\circ} \mathrm{C}$ in the laboratory study, a greater difference was expected also for this organism. A previous Swedish study reported lower inactivation for coliform bacteria after mesophilic digestion, $1-2 \log _{10}$, compared to the $2-4 \log _{10}$ reduction observed for thermophilic digestion (SVA, 2001). After thermophilic treatment the densities of both coliforms and enterococci were below the detection limit. However, after further treatment of the sludge by centrifugation the enterococci were back to similar levels as found in sludge subjected to mesophilic treatment (SVA, 2001). Thus, it is of great importance where in the process samples are taken in order to evaluate the efficiency of the treatment.

Further evaluation of the usefulness of various indicators for quality control and validation of sludge treatment methods is anticipated. Even if the organisms included in this study did not show significant differences in the relative efficiency of the mesophilic and thermophilic treatments, it may well be those other microorganisms behave differently. Since it is known that a higher temperature result in a more rapid inactivation of pathogenic microorganisms, it is therefore still justified to apply thermophilic temperatures when treating sludge. Previous studies to evaluate the effect of high $\mathrm{pH}$ through addition of lime on survival of the parasite Ascaris in faeces resulted in the conclusion that temperature played a more significant role than $\mathrm{pH}$, at least above $25 \mathrm{C}$. Difficulties to achieve conditions at a laboratory conditions similar to a full scale when adding quick lime to sewage sludge was experienced by Paulsrud et al. (2004). Höglund and Stenström (1999) investigated the effect of $\mathrm{pH}$ on the viability of Cryptosporidium oocysts and concluded that other factors than $\mathrm{pH}$ influenced the die-off effect of (oo)cysts in urine. 
Even if the FISH-method seems to be the most promising in vitro viability method, there are still some uncertainties regarding viability measurements of Giardia and Cryptosporidium. Correct results are needed in order to make appropriate estimates of risks related to wastewater and sludge, as well as other environmental sources. In future studies it would also be informative with knowledge about the different genotypes of Giardia and Cryptosporidium found that could give information about possible presence of human pathogenic species and subspecies.

According to the NRC (2002) a number of epidemiological studies and risk assessments are needed in order to get more clarity in how high the risks associated to sludge are and how they should be handled. The results obtained in this study could be used as valuable background material in such studies. 


\section{Conclusion}

This study makes clear that viable Giardia cysts and to a lesser extent Cryptosporidium oocysts is present in high concentrations in the raw sewage and further concentrated in the raw sludge from sewage treatment facilities. The high concentrations of (oo)cysts in the sludge may be a health risk if the sludge is not properly treated. Sufficient die-off was achieved within a few days in laboratory scale experiments in both $50^{\circ} \mathrm{C}$ and $35^{\circ} \mathrm{C}$. In $10{ }^{\circ} \mathrm{C}$ the survival was prolonged to 3 weeks. An initial dieoff was observed within the first day even in $10^{\circ} \mathrm{C}$ and other factors than temperature are believed to influence the inactivation. This effect did not occur in water samples. It is believed that properly treated sludge is not a significant factor for transmission of infectious (oo)cysts. The FISHmethodology was useful for Cryptosporidium in controlled laboratory experiments, but was difficult to interpret for Giardia cysts from sludge in field samples. For future studies it would be interesting to investigate the presence of different species and subtypes occurring in sludge and sewage for potential human infective transmission. 



\section{References}

Akiyoshi DE, Dilo J, Pearson C, Chapman $\mathrm{S}$, Tumwine J, Tzipori S. Characterization of Cryptosporidium meleagridis of human origin passaged through different host species. Infect Immun 2003

Apr;71(4):1828-32

Albrechtsen HJ. Microbiological investigations of rainwater and graywater constructed for toilet flushing. Water Sci Technol. 2002;46(6-7):311-6

Appelbee AJ, Frederick LM, Heitman TO, Olson ME. Prevalence and genotyping of Giardia duodenalis from beef calves in Alberta, Canada.Vet.Parasitol 2003; Mar 25;112(4):289-94.

Bergen kommune 2005. Giardia-utbrottet I Bergen hösten 2004.

http://www.bergen.kommune.no/info

Bjorkman C, Svensson C, Christensson B, de Verdier K. Cryptosporidium parvum and Giardia intestinalis in calf diarrhoea in Sweden. Acta Vet Scand. 2003;44 (3-4):145-52

Bridgman SA, Robertson RMP, Syed Q, Speed N, Andrews N, Hunter PR Outbreak of cryptosporidiosis associated with a disinfected groundwater supply. Epidemiol Infect 1995;115:555-566

Caccio S, Homan W, Camilli R, Traldi G, Kortbeek T, Pozio E. A microsatellite marker reveals population heterogeneity within human and animal genotypes of Cryptosporidium parvum. Parasitology 2000;120 237-244

Caccio SM, De Giacomo M, Anlicino FA, Pozio F. Giardia cysts in wastewater treatment plants in Italy. Appl Environ Microbiol 2003 Jun;69(6):3393-8.

Cacciò SM, Giacomo MD, Francesca A. Aulicino, Pozio E. Giardia Cysts in Wastewater Treatment Plants in Italy. Int. J Parasitol 2002; 32: 1023-1030.

Caccio SM, De Giacomo M, Pozio E. Sequence analysis of the beta-giardin gene and development of a polymerase chain reaction-restriction fragment length polymorphism assay to genotype Giardia duodenalis cysts from human faecal samples. Int J Parasitol.2002 Jul;32(8):1023-30
Comez-Couso H, Freire-Samos F, Martinez-Urtaza J, Garcia-Martin O, AresMaza's ME Contamination of bivalve molluscs by Cryptosporidium oocysts: the need for new quality control standards. Int J Food Microbiol 2003;87: 97-105

Corona-Vaszuez B, Samuelson A, Rennecker JL, Marinas BJ. Inactivation of Cryptosporidium parvum oocysts with ozone and free chlorine. Water Res. 2002;34:4325-32

Craun GF, Calderon RL, Craun MF. Outbreaks associated with recreational water in the United States. Int J Environ Health Res. 2005 Aug;15(4):243-62

Davies CM, Altavilla N, Krogh M, Ferguson CM, Deere DA, Ashbolt NJ. Environmental inactivation of Cryptosporidium oocysts in catchment soils. Journal of Appl Microbiol 2005,98;308-17

Deere D, Vesey G. Milner M, Williams N, Ashbolt N, Veal D. Rapid method for fluorescent in situ ribosomal RNA labelling of Cryptosporidium parvum. Journal of Appl Microbiol 1998, 85; 807-18

Dorsch MR, Veal DA. Oligonucleotide probes for specific detection of Giardia lamblia cysts by fluorescent in situ hybridization. J Appl Microbiol. 2001 May;90(5):836-42.

EC. 2000. Working document on sludge, $3^{\text {rd }}$ draft. European Communities, Brussels.

EC. 2001. Evaluation of sludge treatments for pathogen reduction - final report. European Communities, Luxemburg.

Elliot A, McInnes L, Traub R, Besier B. Sheep may not be an important zoonotic reservoir for Cryptosporidium and Giardia parasites. Appl Environ Microbiol 2005 Sep; 71(9): 4992-7.

Enemark HL, Ahrens P, Lowery CJ, Thamsborg SM, Enemark JMD, BilleHansen V, Lind P. Cryptosporidium andersoni from a Dansh cattle herd: identification and preliminary characterisation. Vet Parasitol 2002;107 (222) 37-49

Enemark HL, Ahrens P, Juel CD, Petersen E, Petersen RF, Andersen, Lind $P$, 
Thamsborg SM. Molecular characterization of Danish Cryptosporidium parvum isolates. Parasitology 2002 Oct; 125(Pt4):331-41

EPA, Environmenal Protection Agency. Method 1623; Cryptosporidium and Giardia in water by filtration/IMS/IFL Eurosurveillance 2005;10(10:051027).

Fayer R. Effects of high temperature on infectivity of Cryptosporidium parvum oocysts in water. Appl Environ Microbiol 1994;60;2732-5

Fayer R, Trout JM and Jenkins MC. Infectivity of Cryptosporidium parvum oocysts stored in water at environmental temperatures J parasitol 1998:84:1165

Fayer R. Trout JM, Nerad T. Effects of a wide range of temperatures on infectivity of Cryptosporidium parvum oocysts. J Eukaryot Microbiol 1996;43(5:64S

Fayer R Effect of sodium hypochlorite exposure on infectivity of Cryptosporidium parvum oocysts for neonatal BALB/c mice. Appl Environ Microbiol 1995;61(2):844-6

Freire-Santos F, Oteiza-Lopez AM, Vergara-Castiblanco CA, Ares-MazasE, Alvarez-Suarez F, Garcia-Martin O. Detection of Cryptosporidium oocysts in bivalve molluscs destined for human comsumption. J Parasitol 2000;86(4):853-4

Gasser RB, Abs El-Osta UG, Chalmers RM. Electrophoretic analysis of genetic variability within Cryptosporidium parvum from imported and autochtonous cases of cryptosporidiosis in the United Kingdom. Appl Environ Microbiol 2003; 69, 2719-2730

Gennaccaro A, McLaughlin Mr, QuinteroBetancourt W, Huffman DE, Rose JB. Infectious Cryptosporidium parvum oocysts in final reclaimed effluent. Appl Environ Microbiol. 2003

Aug;69(8):4983-4.

Giangaspero A, Paoletti B, Iorio R, Traversa D. Prevalence and molecular characterization of Giardia duodenalis from sheep in central Italy. Parasitol Res 2005 Apr;96(1):32-7

Graczyk TK, Grimes BH, Knight R, Da Silva AJ, Pieniazek NJ, Veal DA. Detection of Cryptosporidium parvum and Giardia lamblia carried by synanthropic flies by combined fluorescent in situ hybridization and a monoclonal antibody.

Am J Trop Med Hyg. 2003

Feb;68(2):228-32.
Graczyk TK, Conn DB, Marcogliese DJ, Graczyk H, Lafontaine Y. Accumulation of human waterborne parasites by zebra mussels (Dreissena polymorpha) and Asian freshwater clams (Corbicula fluminea). Parasitol Res 2003 Jan;89(2):107-12

Guy RA, Payment P, Krull UJ, Horgen PA. Real-Time PCR for Quantification of Giardia and Cryptosporidium in Environmental Water Samples and Sewage. Appl Environ Microbiol 2003:5178-85

Haas C, Kaymak B. Effect of initial microbial density on inactivation of Giardia muris by ozone. Water Res. 2003;37,2980-88

Horan N, Fletcher L Lowe P. The fate of pathogens in sewage sludge processing. CIWEM- Biosolids at the risk and benefits, an update on the latest research, London 9 january 2002.

Hsu BM, Yeh HH. Removal of Giaria and Cryptosporidium in drinking water treatment, a pilotscale study. Water Res. 2003 Mar;37(5):1111-7

Hamnes SI, Gjerde B, Robertson L, Vikoren T, Handeland K. Prevalence of Cryptosporidium and Giardia in freeranging wild cervids in Norway. Vet Parasitol 2006;10;141(1-2):30-41

Hanninen ML, Horman A, RimhanenFinne R, Vahtera H, Malmberg S, Herve S, Lahti K Monitoring of Cryptosporidium and Giardia in the Vantaa river basin, southern Finland. Int J Hyg Environ Health. 2005;208(3):163-71

Hansen A and Stenström T-A. Kartläggning av Giardia och Cryptosporidium i svenska ytvattentäkter. Smittskyddsinstituet och Livsmedelsverket 1998 ISBN 1400-3473

Hunter R P and Thompson RCA. The zoonotic transmission of Giardia and Cryptosporidium. Int J Parasitol 2005;35(11-12)1181-90

Höglund CE, Stenström TA. Survival of Cryptosporidium parvum oocysts in source separated human urine. Can J Microbiol. 1999. Sep:45(9):740-6

Hörman A, Rimhanen-Finne R, Maunula $\mathrm{L}$, von Bonsdorff $\mathrm{CH}$, Torvela $\mathrm{N}$, Heikinheimo A, Hanninen ML. Campylobacter spp, Giardia spp, Cryptosporidium spp., Noroviruses, and indicator organisms in surface water in southwestern Finland, 2000-2001. Appl Environ Microbiol. 2004 Jan;70(1):87-95. 
Hörman A, Korpela H, Sutinen J, Wedel H, Hänninen M-L. Meta-analysis in assessment of the prevalence and annual incidence of Giardia spp. and Cryptosporidium spp. infections in humans in the Nordic countries. Int J Parasitol. 2004;(34):1337-46

Insulander M, Lebbad M, Stenström T-A, Svenungsson B. An outbreak of cryptosporidiosis associated with exposure to swimming pool water. Scand J Infect Dis; 2005; 37: 354-360

Irwin PJ (2002). Companion animal parasitology; a clinical perspective. Int J Parasitol 2002:32, 581-593

Jenkins MB, Trout JM, Higgin JA, Dorsch M, Veal D, Fayer R. (2003) Comparison of tests for viable and infectious Cryptosporidium parvum oocysts. Parasitol Res 2003;89:1-5

Jenkins MB, Walker MJ, Bowman DD, Anthony LC, Ghiorse WC. Use of a sentinel system for field measurements of Cryptospordidium parvum oocyst inactivation in soil and animal waste. Appl Environ Microbiol 1999; 1998-2005

KLT- National Public Health Institute (Finland) http://www.ktl.fi

Kato S, Fogarty E, Bowman DD. Effect of aerobic and anaerobic digestion on the viability of Cryptosporidium parvum oocysts and Ascaris suum eggs. Int J Environ Health Res 2003,13:169-179

Kemper N, Aschfalk A, Arnemo JM, Holler C. Prevalence of enteropathogenic bacteria and Cryptosporidium species in moose (Alces alces) in Norway.Vet Rec. 2004 Jun 26;154(26): 827-8

Korich DG, Mead JR, Madore MS, Sinclair NA, Sterling CR. Effects of ozone, chlorine dioxide, chlorine and monochloramine on Cryptosporidium parvum oocysts viability. Appl Environ Microbiol 1990;56(5):1423-8

Kärrman, E., Berg, P.G., Olin, B., Palme, U., Rydhagen, B., Schönning, C., Söderberg, H. and Tälleklint, M. 2005. Sustainable sewerage systems in Uppsala (Uthålliga spillvattenssystem $i$ Uppsala). Report 2005:9, Urban Water, Göteborg, Sweden. (In Swedish, English summary).

Laakkonen J, Soveri T, Henttonen H. (1994) Prevalence of Cryptosporidium $s p$. in peak density Microtus agrestis, Microtus oeconomus and Clethrionomys glareolus populations. J Wildl Dis. 1994 Jan;30(1):110-1.

Heinicke G and Stenström T-A. Chapter 7; Drinking water treatment and supply.in Strategic planning of sustainable urban water management (Eds Malmqvist P-A, Heinicke G, Kärrman E, Stenström T-A, Svensson G). IWA Publishing, Alliance hourse, 12Caxton Street, London SW1H0QS,UK.

Le Chevallier MW, Norton WD, Lee RG. Occurrence of Giardia and Cryptosporidium spp. in surface water supplies. Appl Environ Microbiol 1991;57(9):2610-6

Ljungström I, Castro B. Immune response to Giardia lamblia in a water-borne outbreak of giardiasis in Sweden. J Med Microbiol. 1992 May;36(5):347-52

Mayer CL, Palmer CJ. (1996) Evaluation of PCR, nested PCR, and fluorescent antibodies for detection of Giardia and Cryptosporidium species in wastewater. Appl Environ Microbiol 1996;62(6):2081-5

Mac Kenzie WR, Hoxie NJ, Proctor ME, Gradus MS, Blair KA, Peterson DE, Kazmierczak JJ, Addiss DG, Fox KR, Rose JB, Davis JP. A massive outbreak in Milwaukee of Cryptosporidium infection transmitted through the public water supply. N Engl J Med 1994;331(3): 161-7

Massanet-Nicolau J. New method using sedimentation and immunomagnetic separation for isolation and enumeration of Cryptosporidium parvum Oocysts and Giardia lamblia cysts Appl Environ Microbiol 2003;nov:6758-61.

Mc Lauchlin J, Amar C, Pedraza-Diaz S, Nichols G L. Molecular epidemiological analysis of Cryptosporidium spp. in the United Kingdom: results of genotyping Cryptosporidium spp. in 1,705 fecal samples from humans and 105 fecal samples from livestock animals. J Clin Microbiol 2000,Nov;38(11):3984-90

Millard PS, Gensheimer KF, Addiss DG, Sosin DM, Becket GA, Houck-Jankoski A, Hudson A. An outbreak of cryptosporidiosis from fresh-pressed apple cider. JAMA 1994 Nov 23-30;272(20): $85-90$

Neringer R, Andersson Y, Eitrem R. A water-borne outbreak of giardiasis in Sweden. Scand J. Infect Dis. 1987;19(1):85-90 
Linden KG, Shin G, Fauber G, Cairns W, Sobsey MD. UV disinfection of Giardia lamblia cysts in water. Environ Sci Technol. 2002 Jun 1;36(11):2519-22.

National Institute of Public Health (Norway) http://www.fhi.no

Nygård K, Vold L, Robertson L, Lassen J. Underdiagnostiseres innenlandssmittede Cryptosporidium-og Giardia-infeksjoner i Norge? Nor Laegeforen nr. 23, 2003;3406-9

O'Handley RM, Cockwill C, McAllister TA, Jelinski M, Morck DW, Olson ME. Duration of naturally acquired giardiosis and cryptosporidiosis in diary calves and their association with diarrhoea. J Am Vet Med Assoc 1999;214(3):391-6

Ottoson J, Hansen A, Westrell T, Johansen K, Norder H, Stenström T.A. (2005) Removal of noro- and enteroviruses, Giardia cysts, Cryptosporidium oocysts and faecal indicators at four secondary wastewater treatment plants in Sweden. Water Environ Res 2005: 78:

Ottoson J, Hansen A, Björlenius B, Norder $\mathrm{H}$, Stenström TA. Removal of viruses, parasitic protozoa and microbial indicators in conventional and membrane processes in a wastewater pilot plant. Water Res 2006 Apr;40(7):1449-57

Ottoson J. Giardia and Cryptosporidium in Swedish Wastewater Treatment Plants. Vatten 2001 57:283-89 Lund

Parasites in Water. NMR, Nordic Minister of Council Tema Nord report 2003:552

Paulsrud B., Gjerde B. and Lundar A. Full scale validation of helminth ova (Ascaris suum) inactivation by different sludge treatment processes, Water Science \& Technology 2004; 49(10):139-146.

Paymont R, Plante R, Cejka P. (2001) Removal of indicator bacteria, human enteric viruses, Giardia cysts and Cryptosporidium oocysts at a large wastewater primary treatment facility. Can J Microbiol 2001;47(3):188-93

Pedraza-Diaz S, Amar C, McLauchlin J. The identification and characterisation of an unusual genotype of Cryptosporidium from human faeces as Cryptosporidium meleagridis. Microbiol Letter 2000 Aug 15;189(2):189-94.

Pitkälä A, Siitonen A, Hänninen M, von Bonsdorff CH, Ali-Vehmas T, Laakso T, Johansson T, Eklund M, RimhanenFinne R, Maunula L: Sewage sludge and sludge products for agricultural use - a study on hygienic quality. In: Vuorinen
A ed. (LIVAKE 2001-2002). Helsinki: Maa- je metsätalousministeriö, 2003:564. (Maa- ja metsätalousministeriön julkaisuja 2/2003/2003).

Quintero-Betancourt W, Gennaccaro AL, Scott TM, Rose JB. Assessment of methods for detection of infectious Cryptosporidium oocysts and Giardia cysts in reclaimed effluents. Appl Environ Microbiol 2003;sep:5380-88.

Read CM, Monis PT, Thompson RC.

Discrimination of all genotypes of Giardia duodenalis at the glutamate dehydrogenase locus using PCR-RFLP Infect Genet Evol. 2004 June; 4(2)125-30

Rimahanen-Finne R, Hörman A, Ronkainen P, Hänninen ML. An IC-PCR method for detection of Cryptosporidium and Giardia in natural surface waters in Finland. J Microbiol Met. 2002;(50): 299-303

Rimhanen-Finne R, Ronkainen P, Hanninen ML. (2001) Simultaneous detection of Cryptosporidium parvum and Giardia in sewage sludge by IC-PCR. Appl Microbiol. 2001 Dec;91(6):1030-5.

Rimhanen-Finne R, Vourinen A, Marmo S, Malmberg S, Hänninen M-L. Comparative analysis of Cryptosporidium, Giardia and indicator bacteria during sewage sludge hygienisation in various composting processes. Lett Appl Microbiol 2004, 38, p.301-305

Robertson LJ, Campell AT, Smith HV. Survival of Cryptosporidium parvum oocysts under various environmental pressures. Appl Environ Microbiol 1992; Nov: 3494-3500

Robertson LJ, Gjerde B. Occurrence of Cryptosporidium oocysts and Giardia cysts in waters in Norway. 2001 Sep;29(3):200-7

Robertson LJ, Gjerde BK Effects of the Norwegian winter Environment on Giardia cysts and Cryptosporidium oocysts. Microbial Ecology 2004;47; 359-365

Robertson LJ, Greig JD, Gjerde B, Fazol A. The potential for acquiring cryptosporidiosis or giardiosis from consumption of mung bean sprouts in Norway; a preliminary step-wise risk assessment. Int J Food Microbiol 2005;98: 291-300 Robertson L, Gjerde B, Hermansen I, Hamnes IS. Epidemiological investigation of cryptosporidiosis and giardiosis in Norway by anlaysis of sewage influent. Poster presentation Amsterdam 
Giardia/Cryptosporidium conference sept. 2004.

Robertson LJ, Johannessen GS, Gjerde BK, Loncarevic. S. Microbiological analysis of seed sprouts in Norway. Int J Food Microbiol. 2002 May 5;75 (1-2):119-26

Robertson LJ, Gjerde B. (2000) Isolation and enumeration of Giardia cysts, Cryptosporidium and Ascaris eggs from fruits and vegetables. J Food Prot. 2000 Jun;63(6):775-8

Robertson LJ, Gjerde B. Occurrence of parasites on fruit and vegetables in Norway. J Food Prot. 2001

Nov:64(11):1793-8

Robertson ID, Thompson RC Enteric parasitic zoonoses of domesticated dogs and cats. Microbes Infect. 2002 Jul;4(8):867-73

Rochelle PA, Ferguson DM, Handojo TJ, De Leon R, Stewart MH,Wolfe RL. An assay combining cell culture with reverse transcriptase PCR to detect and determine the infectivity of waterborne Cryptosporidium parvum. Appl Environ Microbiol. 1997 May; 5:2029-37.

Rose JB. Occurrence and significance of Cryptosporidium in water. J Am Water Works Assoc 1988;80(2):53-8

Ryan UM, Bath C, Robertson I, Read C, Elliot A, McInnes L, Traub R, Besier B. Sheep may not be an important zoonotic reservoir for Cryptosporidium and Giardia parasites. Appl Environ Microbiol 2005 Sep;71(9):4992-7

Ryan UM, Monis P, Enemark HL, Sulaiman I, Samarasinghe B, Read C, Buddle R, Robertson I, Zhou L, Thompson $\mathrm{RC}$, Xiao L. Cryptosporidium suis sp. (Apicomplexa; Cryptosporidiidae) in pigs (Sus scrofa). J Parasitol 2004; 90,769-73

Sahlström L., Aspan A., Bagge E., Danielsson-Tham M-L., Albihn A. Bacterial pathogen incidences in sludge from Swedish sewage treatment plants. Water Research 2004:38 1989-94

Schönning C. Risker för smittspridning via avloppsslam Redovisning av behandlingsmetoder och föreskrifter. Naturvårdsverkets rapport 5215: 2003

Slifko TR, Friedman D, Rose JB, Jakubowski W). An in vitro method for detecting infectious Cryptosporidium oocysts with cell culture. Appl Environ Microbiol 1997 Sep 63(9)3669-75
Smith HV. Detection of parasites in the environment. Parasitology 1998;117(7):S113-41

Smith JJ, Gunasekera TS, Barardi CRM, Veal D, Vesey G. (2004) Determination of Cryptosporidium parvum oocyst viability by fluorescence in situ hybridisation using a ribosomal RNA-directed probe. J Appl Microbiol 2004,96, 409-417

SMI- Smittskyddsinstitutet http//:www.smittskyddsinstitutet.se Spano F, Putignani L, McLauchlin J, Casemore DP, Crisanti A. PCR-RFLP analysis of the Cryptosporidium oocysts wall protein (COWP) gene discriminated between $C$. wrairi and C. parvum, and between C. parvum isolates of human and animal origin. FEMS Microbiol Lett 1997; 150, 207-217

Swedish EPA. Action plan for recovering of phosphorous from wastewater. (Aktionsplan för återföring av fosfor ur avlopp). Report 5214, Swedish Environmental Protection Agency, Stockholm, Sweden 2002. (In Swedish, English summary).

Swedish EPA. Risks for disease transmission through sewage sludge - Treatment methods and legislation (Risker för smittspridning via avloppsslam - Redovisning av behandlingsmetoder och föreskrifter). Report 5215, Swedish Environmental Protection Agency, Stockholm, Sweden. 2003 (In Swedish, English summary).

Tamburini A, Pozio E. Long-term survival of Cryptosporidium parvum oocysts in seawater and in experimenally infected mussels. Int J Parasitol 1999;87:97-105

Thompson RC. The zoonotic significance and molecular epidemiology of Giardia and giardiasis. Vet parasitol 2004;126:15-35

Thompson RC, Monis PT. (2004) Variation in Giardia:implications for taxonomy and epidemiology. Adv Parastiol 2004;58:69-137

Thompson RC, Morgan UM, Mellor KJ, Hopkin R Genotyping Giardia and Cryptosporidium. Today's Life Science 1999;1180-86

Traub R, Wade S, Read C, Thompson A, Mohammed H. Molecular characterization of potentially zoonotic isolates of Giardia duodenalis in horses. Vet Parasitol 2005 Jun 30;130(3-4):317-21. 
Trout JM, Santin M, Fayer R Identification of assamblage A Giardia in white-tailed deer. Journal of Parasitology 2003;89,1254-1255

Vesey G, Ashbolt N, Fricker EJ, Deere D., Williams KL., Veal DA, Dorsch M. The use of a ribosomal RNA targeted oligonucleotide proves for fluorescent labelling of viable Cryptosporidium parvum oocysts. J Appl Microbiol $1998 ; 85 ; 429-40$

Westrell T, Schonning C, Stenström TA, Ashbolt NJ. QMRA (quantitative microbal risk assessment) and HACCP (hazard analysis and critical control points) for management pahthogens in wastewater and sewage sludge treatment and reuse. Water Sci Technol. 2004;50(2):23-30

Wheeler JG, Swthi D, Cowden JM, Wall PG, Rodriques LC, Tompkins DS, Hudson MJ, Roderick PJ. Study of infectious intestinal disease in England: rates in the community, presenting to general practice, and reported to national surveillance. The Infectious Intestinal Disease Study Executive. BMJ 1999Apr 17;318(7190):1046-50

Whithmore TN and Robertson LJ. The effect of sewage sludge treatment processes on oocysts of Cryptosporidium parvum J Appl Bact 1995;78, 34-8 Zimmer JG, Slawson RM, Huck PM. Inactivation and potential repair of Cryptosporidium parvum following lowand medium-pressure ultraviolet irradiation. Water Res. 2003;37,3517-23

Xiao L, Singh A, Lilmor J, Graczyk TK, Gradus S, Lal AA. Molecular characterisation of Cryptosporidium oocysts in samples of raw surface water and wastewater. Appl Environ Microbiol 2001:67,1097-1101

Xiao L Giardia infection in farm animals. Parasitology Today 1994;10,436-438 